\title{
Promoting Peace and Economic Security in Rwanda Through Fair and Equitable Land Rights
}

\author{
Jamie Crook $\dagger$
}

\section{INTRODUCTION}

Land is part of the common heritage of all Rwandans: past, present, and future generations. ${ }^{\prime}$

Rwanda, the most densely populated country in sub-Saharan Africa, ${ }^{2}$ is facing a land crisis that has begun to destabilize the state's subsistenceagriculture economy and its people's traditionally agrarian way of life. Since emerging from a genocide that killed 800,000 people in three months ${ }^{3}$ and sent close to two million more into exile, ${ }^{4}$ the country has experienced major political and social upheaval, including the challenge of accommodating competing claimants' land rights in the midst of a

Copyright (C) 2006 California Law Review, Inc. California Law Review, Inc. (CLR) is a California nonprofit corporation. CLR and the authors are solely responsible for the content of their publications.

$\dagger \quad$ J.D., School of Law, University of California (Boalt Hall), 2006; A.B. Brown University 2000. I owe my deepest thanks to Professor Kate Jastram and the members of her Spring 2005 seminar, Global Migration, for their contributions and encouragement. In addition to Professor Jastram, I am especially grateful to Shelley Cavalieri, Neha Desai, Steve Swerdlow, and Franeisco Ugarte for their invaluable insight and sensitive engagement with the ideas $I$ have tried to develop in this Comment. Fimally I thank Tina Wong for her exceptionally skilled editing.

I. Organic Law Determining the Use and Management of Land in Rwanda, No. 8 (2005), Official Gazette of the Republic of Rwanda, art. 3. [hereinafter Land Use and Management Law].

2. CIA, The World FACtBooK - Rwanda (June 13, 2006), available at http:/www.cia.gov/ cia/publications/factbook/geos/rw.html (8.4 million people inhabit Rwanda's 26,338 square kilometers).

3. Credible estimates of the death toll range from 500,000 to $1,000,000$. U.N. Secretary-General Kofi Annan has publicly cited 800,000 as the number of deaths. Press Release, U.N. Secretary-General Kofi Annan's Action Plan to Prevent Genocide, U.N. Doc. SG/SM/9197 AFR/893 HR/CN/1077 (July 4, 2004), http://www.preventgenocide.org/prevent/UNdocs/KofiAnnansActionPlantoPreventGenocide 7Apr2004.htm. The Rwandan government released a report citing the death toll at 937,000. U.N. Office for the Coordination of Humanitarian Affairs, Rwanda: Census Finds 937,000 Died in Genocide, Apr. 2, 2004, http://www.irinnews.org/report.asp?ReportlD=40394\&SelectRegion=Great_Lakes\& SelectCountry=RWANDA.

4. U.S. Committee for Refugees and Immigrants, World Refugee Survey 2004 Country Report: Rwanda (2004), http://www.refugees.org/countryreports.aspx?id=158 (last visited May 9, 2005). 
veritable land shortage. In response to the land crisis, the government has pursued policies that have not protected vulnerable segments of its population, including returning refugees and internally displaced persons (IDPs). ${ }^{5}$ Women, who head $34 \%$ of all households in Rwanda, are particularly susceptible to land instability. ${ }^{6}$

Rwanda's land struggles are both a catalyst for and a reflection of the cycle of conflict and migration that has fueled economic and political instability in the Great Lakes region. ${ }^{7}$ Migration into and out of these conflict-ridden states destabilizes land security, complicating the region's struggle for peace and economic growth. ${ }^{8}$ The UNHCR currently ranks Central Africa and the Great Lakes region first among its populations of concern, a group that includes over 1.2 million refugees, almost 27,000 asylum seekers, I08,000 returnees, and hundreds of thousands of internally displaced persons (IDPs). ${ }^{9}$ Fifty years of political turmoil and inter-ethnic conflict in the tiny landlocked nation has prompted large-scale migration into and out of Rwanda, with significant impact on the stability of neighboring countries. Violence and unrest within Rwanda regularly spills over into Burundi and the Democratic Republic of Congo (DRC). Tanzania and Uganda, which have in recent years maintained greater political stability than Burundi or DRC, have nonetheless absorbed millions of Rwandan refugees, at times leading to sporadic political upheaval within their own borders as well. ${ }^{10}$

5. The U.N. High Commissioner for Refugees (UNHCR) uses "returnee" to refer to refugees who return to their country of origin. Rwandans experienced significant internal displacement as well as refugee flight during the early 1990s. While refugees and IDPs have faced different obstacles in seeking to return to their home regions after 1994, both groups have suffered land inseeurity. Throughout the remainder of this paper, "returning people" will refer generically to returning refugees and returning IDPs, unless otherwise noted. I address Rwanda's distinct legal obligations to the two groups in Part I.C.

6. See Jane Ciabattari, From Rwanda's Ashes, Women Are Building Anew, Women's ENEWS, Oct. 2, 2000, http://www.womensenews.org/article.cfm?aid=290 (noting that women, "[a]s subsistence farmers ... had to put their lives and families back together without men to help").

7. The Great Lakes region ineludes Burundi, Democratic Republic of Congo (DRC), the Republic of Chad, Republic of Congo, Rwanda, and Tanzania.

8. See Christopher Huggins, Preventing Conflict through Improved Policies on Land Tenure, Natural Resource Rights, and Migration in the Great Lakes Region, 3 Eco-Conflicts 1 (2004) [hereinafter Huggins, Preventing Conflict] (linking land disputes to conflict in the Great Lakes region and noting that "[I] and tenure can ... be one part of a complieated combination of structural factors contributing to violence").

9. UNHCR, GLOBAL REPORT 200414 (2004).

10. Recent violence and turmoil in western DRC is largely a product of the continuing obstacles to repatriation of Rwandan refugees who have been living in DRC since the mid-1990s. For a brief overview tying the Rwandan refugee situation to internal strife in DRC, see Jens Hesemann, Refugee Return is the Spark of Hope in the Great Lakes, UNHCR, Jan. 6, 2006, http://www.unhcr.org/cgi$\mathrm{bin} / \mathrm{texis} / \mathrm{vtx} /$ news/opendoc.htm?tbl=NEWS\&page=home\&id=43be45274. The UNHCR notes that while 81,000 Rwandan refugees have returned to Rwanda from DRC since 2001, up to 50,000 remain in the forest region of western DRC. Id. The large population of Rwandan refugees has posed an ongoing security threat in DRC, particularly due to the presence of Interahamwe insurgents in the camps and forests. See UNHCR, The State of THE World's RefugeEs 2000: Fifty Years of 
Achieving an equitable system of land allocation is vital to ending the decades-old cycle of armed violence and migration that has plagued Rwanda and its neighbors. In addition to political turmoil, poverty and underdevelopment likewise germinate conflict. ${ }^{11}$ In primarily agrarian societies such as Rwanda's, insufficient land security constitutes a substantial impediment to economic stability and growth by preventing families from meeting their food and housing needs. Despite financial and human capital investment in Rwanda after the genocide, today $70 \%$ of Rwandans live in poverty, at a rate comparable to that before the I994 war. Rwanda ranks nineteenth on the United Nations Development Programme's (UNDP) list of least livable countries and I59th out of I77 countries on the Human Development Index, which computes the comparative measure of a country's well-being based on factors including wealth, education, the availability of health services, and life expectancy. ${ }^{12}$ Achieving security of tenureship for the $94 \%$ of Rwandans who continue to rely on land to support themselves and their families ${ }^{13}$ is imperative to Rwanda's ability to contribute to the region's peace and development. ${ }^{14}$

This is no easy task, however, for land-strapped Rwanda, an impoverished nation still grappling with its recent history of genocide. In addition to its resource limitations, high-volume emigration and immigration present added challenges. In resolving competing claims to land, the Rwandan government faces four complicating factors: (I) most of its rural poor are subsistence farmers with strong familial and cultural ties to their ancestral plots; (2) adherence to traditional patrilineage has decreased the size of most family plots to an unproductive 0.5 hectares or less; ${ }^{15}(3)$ women-

HumanitaRian ACTION 248-49, 272-73 (2000), available at http://www.unhcr.org/pubs/ sowr2000/sowr2000toc.htm. Skirmishes with Congolese and Burundian troops have prompted new Hutu flight, sparking violence in both countries. See Human Rights Watch, D.R. Congo: Fleeing Civilians Face Grave Risks, Dec. 21, 2004, available at http://hrw.org/english/docs/ 2004/12/21/congo9919_txt.htm; Human Rights Watch, Democratic Republic of Congo - Rwanda Conflict, Dec. 4, 2004, available at http://hrw.org/english/docs/2004/12/04/congo9767_txt.htm. Rwandan conflict has historically impacted other neighbors as well: for example, military leaders of the Rwandan diaspora Paul Kagame and Major General Fred Rwigyema helped lead separate attacks on Presidents Idi Amin and later President Milton Obote. See Joel Stettenheim, The Arusha Accords and the Failure of International Intervention in Rwanda, in WORDS OVER WAR: MEDIATION AND Arbitration to Prevent Deadly Conflict 220 (Melanie C. Greenberg et al. eds., 2000).

11. See, e.g., T. Alexander Aleinikoff, International Legal Norms and Migration: An ANALYSIS 53-54 (2002) (noting the links between underdevelopment and migration).

12. UNDP, Human Development Report 2005, Country Fact Sheets-Rwanda, available at http:/hdr.undp.org/statistics/data/country_fact_sheets/cty_fs_RWA.html (last visited May 9, 2005).

13. Human Rights Watch, Uprooting the Rural Poor in Rwanda 1 (2001) [hereinafter HRW, UPROOTING THE RuRal PoOR].

14. Herman Musahara offers the following definition of land tenure: "Tenure refers to the terms and conditions on which land is held and used. Tenure is not a matter of man's relationship to land ... . [but ratherl relationships between individuals and groups of individuals in which rights and obligations with respect to control and use land are defined." Herman Musahara, Land and Poverty in Rwanda, Seminar on Land in Rwanda, (Nov. 22-23, 2001) (Umubano, Rwanda), at 12.

15. Huggins, Preventing Conflict, supra note 8 , at 2. 
who comprise a majority of Rwanda's food suppliers ${ }^{16}$ - still experience disproportionate land insecurity, despite a sharp increase in the number of women-headed households following the genocide; and 4) its parallel legal system offers insufficient judicial remedy when local officials abuse their authority to allocate land rights, leaving vulnerable groups such as women and returning people susceptible to landlessness and its attending challenges. ${ }^{17}$ Land reform initiatives such as the National Habitat Policy (NHP) ${ }^{18}$ the Matrimonial Regimes, Liberties and Succession Law of 2000 (Succession Law) ${ }^{19}$ and the Organic Law Determining the Use and Management of Land of 2005 (Land Use and Management Law) ${ }^{20}$ fail to meet the needs of the country's most disadvantaged members, particularly women and returning people.

This Comment surveys land regulation in Rwanda and evaluates the extent to which the new government's reform efforts have failed to move the country towards greater peace, stability, and prosperity. 1 argue that in failing to promote equitable land access for vulnerable segments of the population such as women and returning people, the Rwandan government has not yet attained a viable strategy for coping with its land crisis, with the ultimate effect of perpetuating further violence and instability in Rwanda and the surrounding region. ${ }^{21}$ The international donor community shares responsibility for this failure. It has not helped Rwanda create a process for resolving land disputes after the genocide, nor has it provided Rwanda with adequate material support to meet its people's basic needs. Moreover, by conditioning aid on the adoption of land reform measures that are at odds with Rwandans' historically more communal conception of land rights, international donors have in fact exacerbated economic and social upheaval in a country in desperate need of stability. Viable land reform for Rwanda requires truly curative measures that are sensitive to the continued impact of the genocide on inter-group relationships and trust; to Rwandans' distinctly communal and cultural connections to land; and to women's special needs, particularly as single parents and widows. A land policy that addressed these factors would promote prosperity and peace in a nation and a region emerging from decades of violence.

16. See infra note 101 and accompanying text.

17. For a description of parallel legal systems generally and Rwanda's in particular, see infra Part 11 , especially note 85 and accompanying text.

18. République Rwandaise, Ministère des Travaux Publics, Politique Nationale de l'Habitat, Dec. 1996, p. 20, cited in HRW, Uprooting the RuRal Poor, supra note 13, at 11

19. The Matrimonial Regimes, Liberties and Succession Law of Mareh 2000, CC No. 22/99 (1999), Official Gazette of the Republic of Rwanda, art. 43 [hereinafter Succession Law].

20. The Rwandan government enacted the Land Use and Management Law on July 14, 2005. See supra note 1. Prior to its enactment, the proposed law was the subject of extensive scholarship. Throughout this Comment, 1 will refer to the newly implemented law as the "Draft Land Law" when citing and discussing its treatment in pre-2005 sources.

21. See supra note 10 and accompanying text. 
Part I of this Comment provides an historical overview of land use in Rwanda through the 1994 genocide and its aftermath. In Part II, I discuss land regulation in post-genocide Rwanda with a particular focus on the interaction between the country's parallel legal system, gender justice, and continued inter-ethnic tensions. I argue that as of yet Rwanda's land policy has not adequately addressed the needs of its most vulnerable citizenswomen and returning people (both returnees and IDPs). Part III explores multinational approaches to land-dispute resolution in other post-conflict settings, drawing distinctions based on Rwanda's unique circumstances as a predominantly rural state with limited judicial resources. In Part IV, I discuss the NHP, the Succession Law, and the Land Use and Management Law, reading them against an international legal framework that mandates special protection for womcn and returning people and that proscribes discrimination based on ethnicity. Part $\mathrm{V}$ concludes with policy considerations that should influence efforts by Rwanda and its international supporters to achieve a viable land policy that meets the needs of all its people.

\section{I \\ LAND USE AND CONFLICT IN RWANDA}

Devising a workable model for addressing Rwanda's current land crisis requires an understanding of the historic salience of land to Rwandans' culture and way of life. As inhabitants of a traditionally rural state, Rwandans have always relied on land for their livelihoods. Each of Rwanda's three cultural groups-Tutsi, Hutu, and Twa-customarily used land in a distinct way: Tutsi herded cattle; Hutu cultivated sustainable crops; and Twa were foresters. ${ }^{22}$ These unique labor patterns, as opposed to sociocultural or linguistic distinctions, characterize the three groups. Customary patterns of settlement in Rwanda differed from those in neighboring states and throughout ccntral and southern Africa, in that geographic clustering in villages traditionally occurred only insofar as different regions were morc apposite for a particular type of land use. Understanding Rwandans' historically disperse patterns of land tenure and settlement is crucial to understanding its present-day struggles to regulate land rights equitably.

\section{A. Land Regulation in the Emerging Pre-colonial State}

From the early 1400s through the mid-nineteenth century, Rwanda underwent a gradual process of state formation that reached its zenith under Tutsi Mwami (King) Kigeri Rwabugiri (r. 1860-1895), who reigned

22. The Rwandan population today is approximately $84 \%$ Hutu, $15 \%$ Tutsi, and $1 \%$ Twa. CIA WORLD FACTBOOK, supra note 2. 
over a dramatic territorial expansion and centralization of power. ${ }^{23}$ Prior to this centralization, land use patterns in Rwanda varied from the northern to the southern and central regions. A land tenure system known as ubukonde characterized land allocation in the north and northwest, which were outside the direct control of the centrally-located Tutsi court. The first occupier of an area, generally the male lineage head, or umukonde, allotted usufructuary rights to people in his lineage, and sometimes to people outside the lineage. ${ }^{24}$ Allottees, especially those outside the lineage, expressed gratitude for the grant of land-use rights through voluntary gifts such as cattle or beer, though this umuheto (gift-giving) obligation was informal and never involved labor. ${ }^{25}$

In the southern and central regions, the Tutsi court regulated land use with greater institutional control. Under isambu, or divine-right ownership, all land belonged to the Tutsi mwami. His chiefs, abatware b'umukenke, were responsible for distributing land-use rights to the royalty's subjects, typically in exchange for mandatory labor extractions. ${ }^{26}$ Under the isambu system, grantees were able to alienate their usufructuary rights pursuant to approval by the king's local authority, ${ }^{27}$ as opposed to the lineagerestriction in the north.

Under Mwami Rwabugiri, the Tutsi royal family centralized control of the Rwandan state throughout the second half of the nineteenth century, ${ }^{28}$ often by moving into Hutu-occupied regions and displacing Hutu agriculturalists with their own cattle herds. ${ }^{29}$ Realizing that equitable land regulation was crucial to stability and consequently to political control, Mwami Rwabugiri created a tri-chief system of local governance, with a "chief of the pastures," a "chief of the land," and a "chief of the men." An arrangement more akin to a patron-client hierarchy emerged, with mandatory labor, ubureetwa, replacing the informal gift system of umuheto for

23. See Mahmood Mamdani, When Victims Become Killers: Colonialism, Nativism, and THE GENOCIDE IN RWANDA 61-71 (2001).

24. Laurel L. Rose, Women's Land Access in Post-Conflict Rwanda: Bridging the Gap Between Customary Law and Pending Land Legislation, 13 TEX. J. Women \& L. 197, 207 (2004) [hereinafter Rose 2004].

25. Id.; Mamdani, supra note 23, at 65; Alana Tiemessen, Post-Genocide Rwanda and Villagization: The Human Insecurity of Dwindling Land Entitlements 3 (Mar. 1-5, 2005) (unpublished manuscript, on file with the Annual International Studies Assocation Convention in Honolulu), available at $\mathrm{http}: / \mathrm{www}$.iir.ubc.ca/Papers/Tiemessen-1SA.pdf.

26. Rose 2004, supra note 24 , at 207-08.

27. Harold Liversage, Overview of Rwanda's Land Policy and Land Law and Key Challenges for Implementation, Briefing Document (Feb. 2003), available at www.oxfam.org.uk/what_we_do/issues/ livelihoods/landrights/downloads/overview.rtf (last visited Mar. 31, 2006).

28. The gradual process of centralization culminated during the reign of Mwami Rwabugiri, which spanned the last third of the nineteenth century. Stettenheim, supra note 10 , at 218 . Gaining power over land regulation facilitated the centralization of the monarchy.

29. See id. Though displacement was frequent, "peaceful coexistence" was also possible. Id.

30. ld at 219 . 
those without cattle. Herders could still "pay" for their land rights with cattle; thus by default only Hutu-who did not own cattle but cultivated sustainable crops-were subjected to the ubureetwa labor requirement. ${ }^{31}$ Thus the consolidation of state power tended to centralize land ownership, exerting different costs on Hutu and Tutsi. ${ }^{32}$ Though the centralization of authority resulted in increasingly formalized land regulation, the communal nature of land tenure, in which a central authority owned a community's land and regulated the allocation of tenureship, persisted into the colonial and post-colonial periods.

\section{B. Colonization and Independence}

The arrival of German and Belgian colonizers in Rwanda led to systematic disordering of pre-colonial land-use patterns as the two consecutive occupiers strengthened the centralized royal government's powers. The Belgians dismantled the tri-chief scheme of land regulation Rwabugiri had established, which disrupted the former balance of power that had protected the peasantry's land security ${ }^{33}$ and codified the isambu system of land regulation. This move further centralized power in the Tutsi royalty and threatened social stability in the Hutu northwest, which had relied on the $u$ bukonde system of tenureship. ${ }^{34}$ The Belgians ultimately brought the formerly independent northern regions under central control and institutionalized the policy of labor extractions, but only against Hutu. Thus ethnicity came to take on formal legal meanings in the colonized state, heightening inter-group tension in relation to resources. The cumulative impact of codification and centralization was to reify ethnic difference and to aggravate relations between agrarian Hutu and shepherding Tutsi. ${ }^{35}$

In imposing these legal meanings, the Belgians sought to categorize more rigidly between Hutu and Tutsi than the two groups had previously

31. See Mamdani, supra note 23, at 65-66.

32. Throughout this period, however, and until recently, the northwestern prefectures of Ruhengeri and Gisenyi retained the customary ubukonde land tenureship system, with ownership accruing only after one hundred years of occupancy. See Edict of 530/1 of May 26, 1961, reprinted in William Schabas \& Martin Imbleau, Introduction to Rwandan Law 83 (1997). The Land Use and Management Law of 2005 formally abolished ubukonde. See Land Use and Management Law, supra note 1, art. 86. This provision establishes that abagerewa, or those who were using land under ubukonde, would assume the status of customary tenants. Id.

33. RenÉ Lemarchand, Rwanda and BURUNDI 119-20 (1970).

34. Id. Lemarchand notes that centralization and the attendant shift to the isambu system "deprive[d] the Hutu of opportunities... [and] eliminated the channels of appeal offered by the previous arrangement." Id. at 120.

35. See Rose 2004, supra note 24 , at 207 , for a discussion of the social disruptions resulting from centralization and codification of local-customary land law during colonization. The Rwandan experience mirrors the havoc colonization imposed on land-use patterns throughout sub-Saharan Africa, leaving present-day effects of "land alienation, dualistic systems of land tenure and agrarian production, and racism." Christopher HugGins et al., LAND, Conflict and Livelihoods in the Great lakes Region: Testing Policies to the Limit 4 (2005) [hereinafter Huggins et al. 2005]. 
distinguished on their own. No one theory fully explains the pre-colonial construction of Hutu and Tutsi ethnicities. Some theories are ethnographic or sociobiological. ${ }^{36}$ A more materialist or labor-focused theory hypothesizes that the delineation originally indicated only the groups' divergent ways of livelihood, between Hutu cultivators and Tutsi pastoralists. ${ }^{37}$ The fluidity of the classifications prior to colonization lends some support to this theory. ${ }^{38}$

Whatever the "true" explanation of the origin of Hutu and Tutsi as distinct ethnicities - which is likely a combination of many theoriesEuropean colonizers observed the two groups' differing uses of land and ascribed fixed ethnic identities to those uses. The ruling Belgians imposed an artificial bright-line distinction based on wealth, generally declaring anyone with ten or more cows a Tutsi. ${ }^{39}$ The Belgian colonizers thus codified what had been a more fluid conception of ethnicity by centering it around wealth and relationship to land.$^{40} \ln 1933$, the Belgians conducted a census to classify every individual by ethnicity based on this wealth distinction. Mamdani comments that in assigning legal significance to ethnicity qua wealth, "[f]or the first time in the history of the state of Rwanda, the identities 'Tutsi' and 'Hutu' held permanently. They were frozen."41 With the entire population duly classified, the Belgians then privileged the

36. See generally MAMDAN1, supra note 23, at 41-65, 79-87 (discussing the migration hypothesis, the Hamitic hypothesis, ethnographic studies, and historicity). Mamdani concludes that Hutu and Tutsi are "political identities that changed with the changing history of the Rwandan state." $I d$. at 73.

37. While overlap between agrarian and pastoral usage brought Hutu and Tutsi into conflict even in pre-colonial times, the Twa's reliance on forest usage did not compete with either group. Rwanda's Twa population is generally treated as a distinct, indigenous ethnic group. Because the Twa comprised such a small proportion of the state's inhabitants and due to their nomadic lifestyle as foresters, they remained largely unimpacted.

38. For example, a Tutsi man could become "Hutufied" if he lost all his wealth and cattle, and a Hutu woman could become "Tutsified" if she married into a Tutsi family. Stettenheim, supra note 10, at 218 .

39. See MAMDANI, supra note 23, at $98-99$ (discussing the ten-cow theory as the "prevalent view" but asserting that the Belgians also classified on the basis of genealogy and physiognomy). See also Alison Des Forges, Leave None to Tell the Story: Genocide IN Rwanda 32 (1999) (explaining that in pre-colonial times "“Tutsi' ... apparently first described the status of an individual-a person rich in cattle" but eventually came to describe "the elite group as a whole... [whereas] 'Hutu'-meaning originally a subordinate... came to refer to the mass of ordinary people").

40. See Stettenheim, supra note 10, at 217 ("Always a somewhat fluid identity, the classification has been transformed from a multifaceted social description, often secondary to clan affiliation, to a more rigid social and political ordering imbued with powerful overtones of intellectual superiority and political and economic dominance."); see also MAMDANI, supra note 23, at 99 (claiming that the Belgian colonial authority "racialize[d]" the "sociopolitical distinction" between Hutu and Tutsi); DES ForGes, supra note 39, at 33 (discussing intermarriage between Hutu and Tutsi and a flexible balance of political power between the two groups). Des Forges also reports that by formally registering Rwandas based on ethnicity the Belgians "enhanced the[] importance [of Tutsi and Hutu ethnicities] and changed their character. No longer flexible and amorphous, the categories became ... rigid and permanent ... . Rwandans[] increasingly stressed their separateness . . ." Id. at 38.

41. MAMDANI, supra note 23 , at 101 . 
Tutsi ruling class, with a net effect of provoking further Hutu resentment towards both the colonizers and their royal Tutsi favorites. ${ }^{42}$

In 1949, Rwanda began a U.N.-sponsored process of decolonization. During the 1950s, under U.N.-trusteeship, a small Hutu intelligentsiamostly seminarians and exiles-managed to win some reforms, including the right to vote and access to jobs and low-level political appointments. ${ }^{43}$ As Rwanda approached independence in the late 1950s, Belgian allegiance switched to the growing class of Hutu leaders. ${ }^{44}$ When the Tutsi monarchy collapsed in 1959 and the Belgians began to pull out, Rwanda became a Hutu-controlled republic, led by the Hutu revolutionary party PARMEHUTU (Parti du mouvement de l'émancipation Hutu). Under the veil of its proclaimed "social revolution," the party expounded strong antiTutsi sentiments, as articulated in the Bahutu Manifesto. ${ }^{45}$

Within three years of this ouster and change of power, the gradual centralization of land regulation that had commenced under Belgian rule culminated in the enactment of the state's first constitution. That 1962 document codified colonial land regulations, declaring that presently occupied lands would remain in the occupants' possession; that possession of all presently unoccupied land would vest in the state; that the state claimed ownership of all land, occupied and unoccupied; and that any sale or bequeathal of one's land tenure must be approved through the Ministry of Agriculture. ${ }^{46}$ This constitutionalization of $\mathrm{R}$ wandan land regulation bore minimal actual impact on land regulation, which during colonization had operated on a similar model of centralized ownership and localized allocation of usufructuary rights, as encouraged by bribes and labor. Most land

42. The Belgians discriminated against Hutu in a myriad of deprivations, ineluding education and political participation. See id. at 103-31 (describing, for example, the Tutsification of local administration, Hutu disenfranchisement, and the exclusion of Hutu youths from schools). See also DES FoRGES, supra note 39, at 38 (noting that Tutsi favored by the Belgian eolonial authority "presumed [their] superiority. Meanwhile Hutu, officially excluded from power, began to experience the solidarity of the oppressed.").

43. MAMDANI, supra note 23, at 114-16.

44. Richard H. Robbins has suggested that the Belgians switched allegiances in the late 1950s in response to decolomization campaigns among some Tutsi. Richard H. Robbins, Global Problems and the Culture of Capitalism 295 (1999).

45. The 1957 Bahutu Manifesto called for a Hutu revolution and cited the Tutsi as the primary cause of Rwandan suffering. "[Rwanda's] problem is above all a problem of political monopoly which is held by one race, the Tutsi; politieal monopoly which . . ends up being a cultural monopoly, to the great despair of the Hutu who see themselves condemned to remain forever subaltern manual laborers and still worse, in the eontext of an independence which they will have helped to win without knowing what they are doing." Reprinted in MAMDANI, supra note 23, at 116. See also Stettenheim, supra note 10 , at 220 (discussing the manifesto).

46. See Musahara, supra note 14, at 13 (citing Rwanda Const. art. 108 (1962)). See also Tiemessen, supra note 25, at 3 (noting that the 1962 laws maintained pre-eolonial land regulation patterns and explaining that the Rwandan state owns all land: "one ean only buy access to use land and not ownership of it"). 
remained governed by local-customary rather than formal law. ${ }^{47}$ The new government therefore largely preserved and blended the former practice in both the isambu and ubukonde customary systems of requiring official approval to allocate one's land rights. Through the present day, Rwandan land law has followed this blended model, relying on the communal ownership principles of the historical isambu and ubukonde systems, with ownership residing in a central body-today the state-that allocates usufructuary rights through the organs of local political offices. ${ }^{48}$

The 1962 Constitution therefore laid the foundation for Rwanda's present parallel system of formal and local-customary land regulation. Unlike a common law system, in which judges look to prior case law to fill gaps in existing statutory and constitutional law, under Rwanda's parallel legal system, adjudicators are not bound by prior judicial interpretations of localcustomary law. In the period between 1959 and 1994, marked by two fullblown wars and constant inter-ethnic hostilities, the flexibility of this parallel legal system allowed for arbitrary application of local-customary land law. Abuse of discretionary power in land allocation proved especially disastrous in the post-independence period in Rwanda under Habyarimana's military regime, which actively promoted inter-ethnic hostility and the withholding of land and other vital resources from Tutsi. ${ }^{49}$

Anti-Tutsi oppression and massacres occurred throughout the three decades following independence, causing an estimated 600,000 Rwandans to flee the country between 1959 and $1990 .^{50}$ Contention also roiled within Rwanda's Hutu population, often over land rights and material resources. Joel Stettenheim notes, for example, that as the "Habyarimana regime ... consolidated power at the expense of southern Hutu groups and Hutu from other clans," land use patterns suffered further disruption, creating social chaos. ${ }^{51}$

Landlessness increased throughout the 1980s, and a growing number of young men postponed or forewent marriage for want of land on which to begin a homestead, further contributing to social instability and material

47. See Liversage, supra note 27 , at 3 (noting that $90 \%$ of land remained subject to customary law after independence).

48. See Land Use and Management Law, supra note 1, art. 3. The Ministry of Lands, Environment, Forestry, Water and Mines administers and maintains urban and rural land registration, though formal registration has only occurred on a small scale to date. Eugène Rurangwa, Land Administration Developments in Rwanda, Expert Group Meeting on Secure Land Tenure: "New Legal Frameworks and Tools," U.N.-Gigiri in Nairobi, Kenya, (Nov. 10-12, 2004), at 1.

49. See Chris Huggins \& Herman Musahara, Land Reform, Governance and the Environment: The Case of Rwanda, Paper Prepared for 4th Regional Session of the Global Biodiversity Forum (GBF) for Africa, (Jun. 9-11, 2004), at 5 (noting that after the 1959 revolution "violence resulted in many Tutsi leaving the country, and widespread re-distribution of land ... and associated tenure insecurity linked to land disputes").

50. Stettenheim, supra note 10 , at 220.

51. Id. 
insecurity ${ }^{52}$ Well-founded perceptions of land disparity conjoined with other factors such as a steadily increasing population growth rate, ${ }^{53}$ environmental depletion, ${ }^{54}$ and a crash in the world coffee market in $1989,{ }^{55}$ to burden the country's rural poor. Additionally, the World Bank and the International Monetary Fund (IMF) conditioned aid during this tumultuous time on the adoption of structural adjustment programs (SAPs) that further burdened Rwanda's rural population. ${ }^{56}$ Historian Gérard Prunier understood Rwandans' increasing material despcration when he remarked:

[A]t least part of the reason why [the genocide] was carried out so thoroughly by the ordinary rank-and-file peasant... was the feeling that there were too many people on too little land, and that with a reduction in their numbers, there would be more for the survivors. ${ }^{57}$

Sporadic anti-Tutsi massacres and retaliatory invasions by exile militias persisted throughout the period following the social revolution and the first Tutsi exodus. In 1990, the Rwandan Patriotic Front (RPF), a fullfledged exile army, invaded Rwanda from Uganda with two goals: removing Habyarimana from power and enabling the return of

52. HRW, Uprooting the RURAl Poor, supra note 13, at 6-7.

53. Globalis, Rwanda: Annual Population Growth Rate, http://globalis.gvu.unu.edu/ indicator_detail.cfm?Country $=\mathrm{RW} \&$ IndicatorID $=29$ (last visited May 9, 2005).

54. Valerie Percival \& Thomas Homer-Dixon, Environmental Scarcity and Violent Conflict: The Case of Rwanda, Part $l$, http://www.library.utoronto.ca/pcs/eps/rwanda/rwandal.htm (last visited May 9, 2005).

55. See RoBBins, supra note 44, at 295. Robbins notes that the international response to the crisis-letting the coffee market self-regulate-led coffee prices to drop to 1930s-era lows, to the "devastati[on]" of small farmers in coffee-producing countries. Id.

56. Stettenheim, supra note 10, at 217 (noting that "structural adjustment programs demanded by the World Bank and the International Monetary Fund [in the late 1980s and early 1990s] were particularly hard on Rwanda's peasants" and led to a $40 \%$ drop in the average per capita income between 1989 and 1993. Both the IMF and the World Bank used SAPs to intervene in the economies of debt-ridden development countries and typically involve a combination of international aid conditioned upon mandatory economic reform. See generally Anup Shah, Structural Adjustment, A Major Cause of Poverty (Nov. 20, 2005), http://www.globalissues.org/TradeRelated/SAP.asp. For example, in 1990 the International Monetary Fund imposed an SAP that required Rwanda to restructure its economy in exchange for continued access to much-needed international aid. Richard Robbins has written that this particular restructuring "devalued the Rwandan franc and further impoverished the already devastated Rwandan farmers and workers." RовBiNs, supra note 44, at 296. A second franc devaluation in 1992 further destabilized the economy by inflating the prices of basic necessities while lowering the market value of locally grown crops. Id. See also HUGGINS ET AL. 2005, supra note 35, at 13 (noting that SAPs imposed by the IMF and the World Bank in the Iate 1980s and early 1990s "reduced the external resources available for circulation ... [and] increas[ed] the importance of local resources, such as land. This led to corruption within land administration systems and precluded the effective resolution of injustices over land.").

57. Quoted in Stettenheim, supra note 10, at 217. During the genocide, thirty-one of the thirtytwo people killed in Gisenyi prefecture were Hutu with large land holdings. See also HuGGINS ET AL. 2005, supra note 35, at 17; HRW, Uprooting the RURAL PoOR, supra note 13, at 8 ("The growing poverty and land scarcity fueled the genocide and help to explain the readiness with which the jobless and the landless took to killing Tutsi, whether for immediate payment or in return for the promise of land."). 
hundreds of thousands of Tutsi refugees. ${ }^{58}$ As Habyarimana's state army repulsed the RPF, those in power massacred hundreds of Tutsi inside Rwanda's borders, a pattern of incursion, repulsion, and retaliation that repeated five times before the genocide in $1994 .{ }^{59}$

\section{The 1994 Genocide and Steps Towards Peace}

The cycle of civil war and temporary peace begun in the 1950 s finally captured the world's attention when the shooting down of President Habyarimana's plane on April 6, 1994, sparked a genocide of unprecedented scale. ${ }^{60}$ During the three months between the plane crash and the solidification of RPF control in late July, an estimated 800,000 people died; another two million left their homes for safer regions in Rwanda; and at least 250,000 women were raped as part of the genocide ideology. ${ }^{61}$ As the RPF began building a new government, two million more people, mostly Hutu, fled the country. ${ }^{62}$ This group is commonly termed "new caseload" refugees, while the Tutsi and opposition Hutu who had gone into exile between 1959 and the early 1990s are called "old caseload" refugees. Another 1.5 million new caseload refugees (or more accurately IDPs) fled to the French-controlled "zone turquoise" in the southwest corner of Rwanda; this group of IDPs remained in the camps until the new RFP government's army forced them to return by destroying the camps in the spring of $1995 .^{63}$ Adding to this massive demographic shift, old caseload refugees began returning to Rwanda as soon as the new RPF government formed, feeling safe in returning to a now Tutsi-governed Rwanda. ${ }^{64}$

When the RPF gained control in 1994, the warring parties did not enter into a new peace agreement. Instead, in its official Declaration of July

58. DES ForGEs, supra note 39 , at $48-50$.

59. Id. at $48-64$.

60. Id. at 181 .

61. Human Rights Watch, Struggling to Survive: Barriers to Justice for Rape Victims IN RWANDA, 7 (Sept. 2004) available at http://hrw.org/reports/2004/rwanda0904/ [hereinafter HRW, StRUGgling to SuRvive]. Human Rights Watch describes additional gender-based violence during the genocide:

The forms of gender-based and sexual violence were varied and included individual rape; gang-rape; rape with sticks, guns, or other objects; sexual enslavement; forced marriage; forced labor; and sexual mutilation. Sexual violence was one of many injuries inflicted upon Rwandan women and girls, who were often abused after having witnessed the torture and murder of their family members and the destruction of their homes. According to many personal accounts of the genocide, perpetrators of sexual violence murdered a large number of their victims directly following the sexual assaults.

Id.

62. UNHCR, The Rwandan Genocide and its Aftermath, in UNHCR, THE STATE OF THE WORLD's REFUGEES, supra note 10, at 245.

63. Global 1DP Project, Ensuring Durable Solutions for Rwanda's Displaced People: A Chapter Closed Too Early 4, 7 (July 8, 2005), available at http:/www.idpproject.org [hereinafter Ensuring Durable Solutions].

64. UNHCR, The Rwandan Genocide and its Aftermath, supra note 62, at 255. 
17, 1994, the RPF embraced the 1993 Arusha Accords ${ }^{65}$ and the 1991 Rwandan Constitution as the nation's preeminent law. The 1993 Accords had formalized a short-lived ceasefire and officially welcomed Tutsi back to Rwanda, but that agreement patently failed to create long-term peace between the Hutu government and the then-invading RPF. ${ }^{66}$ In November 1994, eight Rwandan political parties endorsed the RPF's Declaration and signed a Protocol of Agreement that declared these three documents - the 1991 Constitution, the outdated Arusha Accords and the 1994 Declaration - Rwanda's controlling Fundamental Law. ${ }^{67}$

New caseload refugees continued to flee during the genocide's aftermath. From 1994 to 1996, DRC alone received one million new refugees from Rwanda.$^{68}$ As relative stability settled over Rwanda, however, many who had left immediately after the genocide chose to return. A portion of the million-plus new caseload Hutu who had sought refuge in surrounding countries began returning alongside the steady waves of old caseload Tutsi refugees throughout 1995 and 1996. Return rates spiked toward the end of 1996, when 1.3 million people returned within a few weeks. ${ }^{69}$

As new and old caseload refugees alike sought to reclaim their family plots, land disputes arose, but Rwanda lacked effective legal mechanisms to resolve the competing claims. Nor did it have the financial or land resources to meet the immediate shelter and subsistence needs of the millions of returnees. Under the governing Arusha Accords, old caseload refugees who left Rwanda prior to 1983 were urged not to reclaim their lands and instead to accept restitution, which the government never in fact provided. Moreover, the 1993 Accords, signed before the phenomenon of new caseload refugees had arisen, by definition guaranteed property rights only for old caseload returnees and not IDPs or new caseload refugees. ${ }^{70}$

65. Implemented by Law $18 / 93$ of Aug. 3, 1993, cited in SCHABAS \& IMBLEAU, supra note 32, at 11.

66. Key weaknesses in the negotiation process and the actual Accords include a failure of third parties to understand fully: the militancy of extremist Hutu groups; the internal dynamics of the RPF and Hutu-power parties, all of which had several chains of command that slowed negotiations; the skirmishes among the refugee populations, the crisis that had initially spawned negotiations; France's dual policy of providing military support to the Habyarimana government while also facilitating a settlement between the two sides; stingy allocations of U.S. personnel at the talks; and a failure of the third-parties to fulfill their commitments to implementing the Accords once they committed to involvement by virtue of having attended the negotiations at all. Additional problematic factors include the expulsion of the interim prime minister from his political party, as designated by the Accords, and a rift between the United Nations and the Organization of African Unity (OAU), leaving the 2,500 UNAMIR troops the only peacekeeping forces in the region. See Stettenheim, supra note 10, at 222-36 (providing an overview of the events leading up to the genocide).

67. Rwanda adopted a new Constitution in 2003.

68. J.P. Godding, Introduction, in RÉfugiés Rwandais au ZaÏre: Sommes-Nous ENCore Des HoMmes? 17 (J.P. Godding ed., 1997).

69. HRW, UPROOTING THE RuRal POOR, supra note 13, at 8 . This repatriation from refugee camps in Tanzania may have been forced by the Tanzanian government. Id.

70. Id. 
Lacking any provisions for receiving new caseload refugees, the Accords provided no guidance in accommodating this rapid movement of people back into Rwanda.

Without any structures in place to facilitate their return and resettlement, the mostly Tutsi old caseload refugees often took over empty land left behind by those who fled Rwanda during and immediately after the genocide. When the mostly Hutu new caseload refugees began returning in 1995 and 1996, they sought to reclaim their land from new occupants, the old caseload Tutsi. Consequently, land disputes between new and old caseload refugees tended to take on ethnicity-based overtones, with new caseload Hutu resenting what they saw as government favoritism towards old caseload Tutsi. ${ }^{71}$ Field researchers report that some community members, in order to protect their current land holdings from meritorious claims to the same land by arriving Hutu new caseload returnees, have even asserted unfounded accusations of genocidal participation against the Hutu returnees, hoping to manipulate what they perceive to be the government's preferential treatment of old caseload Tutsi returnees in their own favor. ${ }^{72}$

Rwanda's refugee and IDP situation remains at crisis levels. 50,000 Rwandan refugees, most of whom are Tutsi, are yet to be repatriated ${ }^{73}$ The most recent UNHCR Global Report cited unlawful governmental detentions of refugees seeking to return from neighboring countries and expressed concern over the increasingly militarized nature of Rwandan refugee camps in western DRC. ${ }^{74}$ Despite some efforts by the Rwandan government to repatriate several thousand refugees, the UNHCR noted the impossibility of "local integration" given the severe land shortage. ${ }^{75}$ Concerted, effective measures are required to promote their return and to instill lasting peace and security in Rwanda and the surrounding region.

The new government's reliance on an ineffective pre-genocide treaty to resolve property disputes, let alone to secure peace, was naïve at best, and its subsequent land policies have not corrected the insufficiencies of the Fundamental Law to establish a scheme of land rights that would address the needs of the 50,000 Rwandans hoping to return and of the many more inside Rwanda who remain unsettled. In so failing, Rwanda has violated its legal obligation to provide housing security for its people, a duty it

71. This perception was also influenced by the government's slow pace in accepting the new caseload refugees. Millions of refugees living in camps in DRC and Tanzania waited two years to return, as the Rwandan government accepted returnees on an individualized basis rather than en masse, citing inability to provide housing and concerns that the orchestrators of the genocide were among the refugees. See Godding, supra notc 68, at 17.

72. HUGGINS ET AL. 2005, supra note 35, at 30.

73. UNHCR, Global ApPeal 2006 101, 103 (2006) [hereinafter UNHCR, Global APPEAL 2006].

74. UNHCR, GLobal REPORT 2004, supra note 9, at 160.

75. Id. at 161 . 
owes as a signatory to the Banjul Charter, ${ }^{76}$ the International Covenant on Civil and Political Rights (ICCPR), ${ }^{77}$ and the International Covenant on Economic, Social, and CuItural Rights (ICESCR). ${ }^{78}$ Under the leading refugee conventions, to which it is similarly a signatory, Rwanda is also bound specifically to protect Iand rights of returning people. ${ }^{79}$ Yet while the human rights norms set forth in these international treaties should guide the development of Rwandan Iand policy, they have not yet been incorporated into Rwanda's legal landscape. In 2005, the Rwandan government shut down many domestic human rights groups, including the most prominent, the Ligue Rwandaise pour la Promotion et la Défense des Droits de l'Homme (L1PRODHOR), ${ }^{80}$ demonstrating the minimal regard the government currently extends to these norms. In light of this reality, perhaps a stronger rationale for urging Rwanda to realize an equitable method of land allocation is the extent to which land insecurity has contributed to classand ethnicity-based conflict inside its own borders and the disastrous spillover effect throughout the region.

The genocide and 1994 war destroyed much of Rwanda's civil and political infrastructure, including its legal system. Few lawyers remained in Rwanda after the genocide, and as of 2003 the country's legal system was still functioning poorly. ${ }^{81}$ What scanty judicial resources exist have been

76. The African Charter on Human and People's Rights (Banjul Charter) protects the right of all people to property and to state assistance in seeking recovery of property or compensation. OAU Doc. CAB/LEG/67/3/Rev. 5 arts. 14, 21(2); 21 I.L.M. 58 (1982).

77. G.A. Res. 2200, 21 GAOR, Supp. 16, U.N. Doc. A/6316, art. 26, 999 U.N.T.S. 171, 6 I.L.M. 368 (Dec. 16, 1966).

78. Annex to G.A. Res. 2200, 21 GAOR, Supp. 16, U.N. Doc. A/6316, art. 2(2), 993 U.N.T.S. 3, 6 I.L.M. 360 (Dec. 16, 1966).

79. The Organization of African Unity (OAU) established the Convention Goveming the Specific Aspects of Refugee Rights in Africa, ratified by Rwanda in 1979, which stipulates that "[r]efugees who freely decide to return to their homeland, as a result of such assurances or on their own initiative, shall be given every possible assistance by the country of asylum, the country of origin, voluntary agencies and international and intergovernmental organisations, to facilitate their retum." OAU Doc. No. CAB/LEG/24.3, art. 5(5) (June 20, 1974) [hereinafter OAU Convention]. The principal treaty on refugee protections, the 195I Convention Rclating to the Status of Refugees as extended by the 1967 Protocol, defines "rcfugee" and establishes obligations of receiving countries but does not address the rights of refugees or 1DPs returning to their homelands or countries of origin. 189 U.N.T.S. 150 (July 28, 1951) [hereinafter Refugee Convention], as amended by the Protocol Relating to the Status of Refugees, 606 U.N.T.S. 267 (Jan. 31, 1967) [hereinafter Refugee Protocol]. Rwanda joined the Refugee Convention in 1980.

80. Amnesty International, Rwanda: Human Rights Organisation Forced to Close (Jan. 7, 2005), http://www.amnesty.org.uk/news/press/15858.shtml; FIDH, Authoritarian Drifts in Rwanda: Arbitrary Dissolution of the Liguge Rwandaise Pour la Promotion et la Défense des Droits de l'Homme (LIPRODHOR), Member Organisation of the FIDH (July 15, 2004), http://www.fidh.org/ article.php3?id_article $=1657$.

81. See Human Rights First, Prosecuting Genocide in Rwanda (July 1997), http:/www.humanrightsfirst.org/pubs/descriptions/rwanda.htm (noting that as of 1997 Rwanda had only sixteen practicing lawyers); HUMAN RIGHTS WATCH, WORLD REPORT 200374 (2003) available at http://www.hrw.org/wr2k3/ [hereinafter HRW, WORLD REPORT 2003] (discussing the country's overtaxed judicial system). In 2000 , in a report to the Committee on the Elimination of Racial 
allocated primarily to prosecuting genocidal crimes rather than resolving civil claims. ${ }^{82}$ With the country's depleted legal fora still glutted with genocide prosecutions, the government has not earmarked any resources for resolving land disputes arising out of the high volume of return rates after $1994 .^{83}$

Ninety-four percent of all Rwandans still rely on land for their livelihoods. ${ }^{84}$ In addition to the immediate imperatives of maintaining peace and healing its people's physical and spiritual wounds, the combined magnitude of death, emigration, and immigration presented the fledgling government with a land and housing crisis of astronomical proportion. However, Rwanda's leadership has not pursued legislation and policy regarding land regulation that fulfills its legal obligation to protect the land rights of its citizens, particularly those most vulnerable to land insecurity.

\section{II}

Legal Parallelism and Land Regulation After I994

\section{A. Regulating Land Tenureship in a Parallel Legal System}

Like many African states, Rwanda recognizes both formal law and local-customary law. ${ }^{85}$ The governing Civil Code distinguishes between

Discrimination, Rwanda's representative stated that the country had only 236 judicial officers and 379 judges. U.N. Comm. on Elimination of Racial Discrimination [CERD], Summary Record of the 1386th meeting: Rwanda, CERD/C/SR.1386 (July 7, 2000); Rose 2004, supra note 24, at 204 (noting that Rwanda's legal system "was not equipped to meet the new legal needs related to genocidc"). See also Rwanda, War and Peace 295 (J. Tebbs ed., 1999) (noting the lack of defense attorneys and magistrates following the genocide).

82. The Organic Law on the Organization of the Prosecution of Offenses Constituting the Crime of Genocide or Crimes Against Humanity, No. 08/96 of Aug. 30, 1996, Government of Rwanda, Official Journal, Sept. 1, 1996, art. 2, divides into four categories the offenses eligible for prosecution: genocide, crimes against humanity, acts committed "in connection with the events surrounding the genocide and crimes against humanity." The 1996 Law designated property violations as a Category Four crime. Id. art. 2(d). Only Category One crimes, however, for "criminal acts or ... acts of criminal participation [that place the perpetrator] among the planners, organizers, instigators, supervisors and leaders of the crime of genocide or of a crime against humanity," are tried in formal courts. Id. art. 2(a); ch. 5 . The rest are adjudicated before the gacaca tribunals, which offer the benefit of community participation but pose significant due process concerns. See infra note 93 .

83. Rwanda's judicial system did not function at all for ten months during 1994 in order to undergo a rcstructuring process. See UNHCR, GLOBAL REPORT 2004, supra note 9, at 159.

84. HRW, UPROOTING THE RURAL POOR, supra note 13, at 1 .

85. See Land Use and Management Law of 2004, supra note 1, art. 5 (affirming the continued rights to land arising out of customary ownership); id. art. 11 (establishing that land rights can be acquired through both "custom" and "written law"). The newly enacted Constitution grants the judiciary jurisdiction to "provide authentic interpretation of custom which is unwritten and in respect of which the written law is silent." Rwanda CONST. art. 145(13) (2003). See also Rwanda Const. art. 98(2) (1991) (providing that customary law would apply when "not replaced by laws ... [nor] contrary to the Constitution, laws, regulations, public order or morals"). For a more general explanation of legal parallelism, see Rose 2004, supra note 24 , at 208 . So as not to confuse customary qua traditional law with the term of art "customary international law," for my purposes "local-customary law" describes the organic body of localized, uncodified laws that govern a particular culture. "Formal law" is domestic statutory and constitutional law. Rwanda's parallel legal system resembles that of other 
three types of land rights: usus, the right to use land; fructus, the right to enjoy and profit from land; and abusus, the right to dispose of land. ${ }^{86}$ Under the Civil Code, only the state enjoys the last of these rights. ${ }^{87}$ All citizens have rights to water in rivers and lakes, though the state owns the land beneath these bodies of water ${ }^{88}$ As noted above, local officials allocate usufructuary rights to the state-owned land ${ }^{89}$ Though on paper no land market exists in Rwanda, gaps between formal land law and localcustomary practices have propagated a virtual market in which land "sales" and "rentals" - in the form of direct payment to the allocating authoritiesare commonplace. ${ }^{90}$ Much as gifts and labor once functioned as payment for land use rights under the ubukonde and isambu systems, local officials today respond to favors and bribery. ${ }^{91}$ This underground market therefore advantages those with economic and social power in their communities. ${ }^{92}$

Additionally, land claims tend to be resolved through ad hoc adjudication by local officials and gacaca judges, who lack training in formal law. ${ }^{93}$ These institutions risk substantial irregularity and subjectivity. ${ }^{94}$ Authorities resolve disputes between the three categories of returning

decolonized African states, emerging out of the imposition of European colonial laws onto traditional legal and social structures. See, e.g., Adrien Katherine Wing \& Tyler Murray Smith, The New African Union and Women's Rights, 13 Transnat'L L. \& Contemp. Probs. 33, 38 (2003).

86. Schabas \& Imbleau, supra note 32, at 96-97.

87. See Land Use and Management Law, supra note 1; Musahara, supra note 14, at 13; See also Rose 2004, supra note 24, at 217 (citing CC No. 09/76A). Land inside Kigali ville, however, is now held by private title. $I d$. at 205 .

88. Schabas \& ImbleaU, supra note 32, at 96 (describing CC 11, arts. 14, 19). This allocation has been preserved in the Land Use and Management Law of 2005, supra note 1, arts. 11, 13 .

89. Rose 2004, supra note 24 , at 205 . Rwanda's political subdivisions, from smallest to largest, progress from colline, to cellule, to commune, and finally to préfecture, of which there are twelve. Bourgmestres head the communes and could be considered as analogous to county councilmembers in the United States.

90. See Rose 2004 , supra note 24 , at $217-18$. See also Tiemessen, supra note 25 , at 4 ("Increases in land scarcity and degradation have resulted in increased illegal transactions and an erosion of both customary and written laws.").

91. Rose 2004, supra note 24 , at $226,238,247$.

92. See id. at 218 ("[I]nconsistencies between law and practice [give] rise to legal uncertainty ... illegal land transfers ... [and] tenure insecurity.").

93. A law passed in April 2002 created 11,000 gacaca jurisdictions. Literally "grass courts," gaeaca reflect a tradition of localized conflict resolution that utilizes participatory justice. Jurist, Rwanda: Constitution, Government \& Legislation, http://jurist.law.pitt.edu/world/rwanda.htm (last visited May 9,2005 ). In a national election Rwandans elected more than 200,000 gacaca judges to head these tribunals. Most gacaca judges are respected figures in their communities but lack formal training. HUMAN RIgHTS WATCH, WORLD REPORT 2002, available at http://www.hrw.org/wr2k2/ [hereinafter HRW, WORLD REPORT 2002].

94. See HRW, WORLD REPORT 2003, supra note 81, at 63 ("Gacaca raised several human rights concerns. The accused, for example, have no right to legal counsel. Given the poor training of judges, defendants aecused of similar crimes may be classed in different categories, resulting in sentencing disparities. The impartiality of judges was raised in several communities and in several cases those aecused of having themselves participated in the genocide resigned... There is no protection for witnesses and detainees, who testify publicly, thus making it difficult for Tutsi-a small minority in most communities-to accuse others."). 
people-IDPs and old and new caseload refugees-in piecemeal fashion. As Rose observes, "the law [is] being interpreted and legal institutions [are] being reinvented in various ways from community to community on a day-to-day basis. The nature and extent of the variations [depend] upon the perceived needs and inventiveness of each community's leaders and citizens." 95

The new government has not enacted policies that correct the parallel legal system's inability to establish an equitable scheme of land rights. Instead, it has created further confusion as to whose land rights should prevail when disputes arise. In response to the increasing rates of return, for example, a 1996 order announced that the "personal or collective private property" rights of current occupants were inviolable, but also perplexingly declared that all returning people-in which it included, without distinction, new and old caseload refugees, but not IDPs-had an enforceable claim to any land rights they had legitimately enjoyed before they left Rwanda. ${ }^{96}$ Under this order, a given plot was susceptible to competing, equally virtuous claims between an old caseload refugee who had left in 1959 and a new caseload refugee who may have occupied the plot for two decades before fleeing after the 1994 genocide. The order did not offer any guidance for resolving this kind of confusion, leading one new caseload returnee to declare, "What is obscure is the policy. They just leave people to settle it themselves. If only the state said, divide the land this way or that way.""97

These gaps most often accrue to the advantage of those with social standing in their communities, who tend not to be women or ethnic outsiders. An example recounted by Human Rights Watch demonstrates that this informality benefits those who are able to evoke the sympathy of others in their host communities. One man returning in 1997, for example, reported that the earlier returnees occupying his property "remembered him fondly from decades before" and lent him a house. ${ }^{98}$ Ultimately they sold him back part of his own property "in an informal and unregistered transaction."99 Other returning people with political connections have turned to local officials and army members for assistance. Those with disposable cash have even greater success obtaining favorable allocations. These examples indicate that, absent more formalized regulation, informal

95. Rose 2004, supra note 24 , at 206.

96. Republic of Rwanda, Ministerial Order No. 01/96 of Sept. 23, 1996, Regarding the Temporary Management of Land Property, cited in HRW, UPRoOTING THE RURAL Poor, supra note 13 , at 47 (declaring that " $1 t$ ] he legitimate owner of the land is reinstated in his property rights upon his return" and mandating a fifteen-day limit on resolving any disputed claims).

97. Human Rights Watch Interview, Kigali (May 27, 2000) cited in HRW, UPROOTING THE RURAL PooR, supra note 13, at 48.

98. Id. at 49.

99. Id. 
influence, wealth, and appeals to in-group affinity benefit some, to the disadvantage of those who would not traditionally have enjoyed land access, including ethnic outsiders and women. ${ }^{100}$

\section{B. Gender Justice and Land Access in a Parallel Legal System}

Because of the central role that agrarian women play in food production, an efficacious development strategy in any agrarian economy should place particular emphasis on protecting women's land rights. Women in sub-Saharan Africa assume a majority of child-rearing and food-production responsibilities. ${ }^{101}$ Restrictions on their ability to own, occupy, and inherit land hinder the ability of women in war-torn agrarian societies like Rwanda's to feed their families. Rasna Warah aptly captured the gendered challenges of rebuilding a stable society in Rwanda when she noted:

The burden of re-building war-torn societies often falls on women and girls whose male relatives-husbands, fathers, brothers and sons-are either killed in the conflict or are absent fighting in wars. However, because of discriminatory customary laws, many returnee women find that they have little or no access to land or property left behind by male meinbers of the family.... This means that women have no access to land on which they can grow food to feed their families.... Moreover, they are rendered homeless as they have no claim to the property left behind by their husbands or fathers. ${ }^{102}$

But in Rwanda, as in several sub-Saharan African states, women have historically been denied the right to inherit or otherwise obtain land access. Using pre-1994 Rwanda as an example, the then-governing Constitution bolstered traditional norms against women's right to own or inherit by declaring them legally incompetent to do either. J. Tebbs has noted that under that document, "a woman [could] own nothing legally, neither house, tools, livestock, nor crops." 103

Land inheritance in Rwanda has traditionally been restricted to sons, and women historically could not inherit or otherwise acquire land-use rights. ${ }^{104}$ While a husband could "dedicate" land to his wife during

100. See infra, Part II.B.

101. Conference Brief from the International Food Policy Research Institute, Increasing the Effective Participation of Women in Food and Nutrition Security 2 (2004) (noting rural African women's "key role" in feeding their nations and the exacerbated effects of gender gaps in wealth and land resources on food production).

102. Rasna Warah, Rwanda Women to Inherit Property, The EAst AfriCan (Apr. 10-16, 2000), available at http://www.unhabitat.org/HD/hdv6n2/rwanda_law.html.

103. RWANDa, War and Peace supra note 81, at 20-21.

104. From a purely pragmatic analysis, Rwanda's "egalitarian" model of patrilineage, in which all sons tend to inherit some land, has been ill-suited to such a densely populated country. The size of the average family plot has decreased by $400 \%$ since 1960 , to its current size of less than 0.5 hectare; if the population continues to increase at its present rate, by 2020 that size will be halved again. Huggins, 
marriage, rigid adherence to patrilineage mandated that any wife who survived her husband could hold his land only provisionally until her sons reached maturity and took possession. ${ }^{105} \mathrm{~A}$ widow without sons was expected to return the land to her husband's family, who had discretion to let her continue occupying the land. ${ }^{106}$ Under no circumstances could she bequeath the land to any daughters or family members outside the deceased husband's lineage. Brotherless women were able to receive land from their fathers when their maternal family lacked sons, but this did not constitute a guaranteed land right beeause a woman's authority over land "given" to her remained contingent on the good will of her male relatives. ${ }^{107}$

Rwanda is currently bound by domestic and international law to uphold women's right to inherit land, ${ }^{108}$ yet the country's parallel legal system does not sufficiently promote women's land rights. Under this parallel system, local-customary law governs in the absence of superseding formal law, particularly in areas salient to women: family law, inheritance law, and property law. ${ }^{109}$ While formal Rwandan land law does not affirmatively discriminate against women, it fails to uphold women's right to equal land access because it leaves space for subjective interpretations of

Preventing Conflict, supra note 8, at 2. In contrast, the U.N. Food and Agriculture Organization (FAO) estimates that an economically sustainable farm should extend at least 0.90 hectare. Global IDP Database, Profile of Internal Displacement: Rwanda, Compilation of the Information Available in the Global IDP Database of the Norwegian Refugee Council, July 23, 2003, http:/www.internaldisplacernent.org/8025708F004BE3BI/(httpInfoFiles)/59C7BF08I8FE4EIE802570BA0053CC0F/\$fil e/Rwanda+-July+2005.pdf.

I05. Rose 2004, supra note 24, at 208-09.

106. Id. at 210 .

107. Id.

108. Rwanda's Succession Law protects women's inheritance rights. Rwanda is also a party to the Convention on the Elimination of All Forms of Discrimination Against Women (CEDAW), which establishes women's substantive rights to state protection from discrimination and to the provision of social services that meet women's specific needs. See CEDAW, G.A. Res. 180, 34 GAOR Supp. 46, U.N. Doc. A/34/46, art. 2, I249 U.N.T.S. 13, 19 I.L.M. 33 (Dec. I8, 1979) ("Statcs Parties condemn discrimination against women in all its forms, agree to pursue by all appropriate means and without delay a policy of eliminating discrimination against women ....'). The CEDAW Committee explicitly incorporated the equal right to inheritance in its interpretation of the treaty's non-discrimination regulations: "There are many countries where the law and practice concerning inheritance and property result in serious discrimination against women.... Such provisions contravene the Convention and should be abolished." CEDAW Committee, General Recommendation No. $2 l$, para. 35. Rwanda has not submitted a report to the CEDAW Committee since 1993

As a signatory to the ICCPR and the ICESCR, the Rwandan state may not practiee gender-based discrimination, either affirmatively or by omission. See ICCPR, supra note 77, art. 26 ("AIl persons are equal before the law and are entitled without any discrimination to the equal protection of the law. In this respect, the law shall prohibit any discrimination and guarantee to all persons equal and effective protection against discrimination on any ground such as race, colour, sex, language, religion, political or other opinion, national or social origin, property, birth or other status."); ICESCR, supra note 78, art. 2(2) ("The States Parties to the present Covenant undertake to guarantee that the rights enunciated in the present Covenant will bc exercised without discrimination of any kind as to race, colour, sex, language, religion, political or other opinion, national or social origin, property, birth or other status.").

109. Wing \& Smith, supra note 85 , at 38-39. 
local-customary law by local officials. In the absence of contradictory or controlling formal law, an adjudicator can resolve a dispute by interpreting uncodified local-customary law, which tends to impede women's equal land access. ${ }^{110}$ This effectively allows Rwanda to circumvent its duty to uphold women's land rights under domestic and international law. In creating this discretionary legal space, Rwandan law does not prevent adjudicators, who are often low-level appointees rather than formally trained jurists, from applying customary law in discriminatory ways. ${ }^{111}$

Changing demographics demand that the Rwandan government intervene in local-customary laws and practices that present continued obstacles to women's land rights. The link between development and women's economic empowerment is especially apparent in Rwanda, where women produce $70 \%$ of the nation's food supply. ${ }^{112}$ At the end of 1994 its population was $70 \%$ women. Today, women are $54 \%$ of the population and single parents to $35 \%$ of Rwandan families. ${ }^{113}$ Rwandan women have faced unique challenges since the genocide, including the burden of providing for their families without the support of spouses and other family members killed in the genocide. ${ }^{114}$ Inequitable access to cultivable land has added

110. The 1991 Constitution, for example, provided that customary law would apply when "not replaced by laws ... [nor] contrary to the Constitution, laws, regulations, public order or morals." RWANDA CONST. art. 98(2) (1991). The newly enacted Constitution grants the judiciary jurisdiction to "provide authentic interpretation of custom wbich is unwritten and in respect of whicb the written law is silent." RWANDA CONST. art. 145(13) (2003). See also Rose 2004, supra note 24, at 208

111. Rose has suggested that this state of legal flux presents an opportunity for some women to acquire land rights formerly unavailable to them under local-customary law. Her research revealed that women with legal savvy and financial means were able to exploit the gaps between local-customary and formal land law to their advantage. Rose has concluded that "women ... have become creative interpreters of unclear or changing norms, laws, and practices ... filling in the gaps within and between land tenure systems." Rose 2004 , supra note 24 , at 220 . Yet this may paint too bright a picture to reflect accurately the circumstances of the majority of Rwandan women who lack access to the social or financial resources necessary to assert their land rights in formal tribunals, and for whom the power to manipulate the system's gaps consequently lies beyond reach. While a few elite women and men may have benefited from the confusion generated by the inconsistencies of the parallel legal system, the majority of Rwandans who lack both formal education and material wealth require more affirmative legal protection.

112. Heather B. Hamilton, Rwanda's Women: The Key to Reconstruction, J. Humanitarian AssisTANCE, http://www.jha.ac/greatlakes/b001.htm (last visited May 9, 2005).

113. U.N. Office of the Special Adviser on Gender Issues and Advancement of Women [OSAGI], expert group meeting on "Enhancing Women's Participation in Electoral Processes in Post-Conflict Countries," Strengthening Governance: The Role of Women in Rwanda's Transition - A Summary, U.N. Doc. EGM/ELEC/2004/EP.5, at 5 (Jan. 26, 2004) (prepared by Elizabeth Powley).

114. Among the many indicators of Rwandan women's disadvantage, boys outnumber girls in primary education by a ratio of nine to one. Though fewer women than men were killed in the genocide, $70 \%$ of all female survivors are HIV-infected. Genocide Victims' AIDS Drug Call, BBC News, Apr. 6, 2004, http://news.bbc.co.uk/l/hi/world/africa/3605269.stm. Women are underrepresented in many professions. See HRW, STRUGGLING To SURvive, supra note 61, at 49-50 (reporting women's under-representation in law enforcement vocations). Women and girls also continue to experience domestic violence and sexual assault at high rates. Id. at 12-13. Social stigma surrounding rape has further burdened sexual assault survivors, who report difficulties in meeting their basic material needs when their families and communities turn them away. See id. at I1. War orphans, 
significantly to women's present struggles as single parents and primary producers by limiting their ability to feed themselves and their families. ${ }^{115}$

As it currently operates, the plural legal system tends to work against Rwandan women's ability fully to exploit their land rights. The Rwandan government could realize its domestic and international mandates to respect, protect, and fulfill women's land rights by prosecuting those who withhold land rights from women and educating women about their rights. Rwanda's legislature could also enact legislation protecting women's equal right to own and inherit land more affirmatively than does the Succession Law or Land Use and Management Law, discussed in Part IV. ${ }^{116}$ Instead, Rwandan women continue to fall through the gaps left between localcustomary and formal law. Traditional barriers continue to impede women's ability to secure land access, in spite of formal legal protections that pronounce a gender-neutral right of inheritance. ${ }^{17}$ In addition to the historic ban on women's ability to inherit or own property, intra-familial battles for land threaten women's access and at times subject women to what researcher Rose has identified as "deceptive and even violent tactics that permanently rupture family relationships," such as beatings by family members. ${ }^{118}$

I do not engage in this analysis to reify Rwandan culture as inherently oppressive to women. Too often the discourse of human rights maligns Iocal-customary practices as per se obstacles to women's equality. ${ }^{119}$ This perspective sees culture (as interpreted through customary practices) as the problem, and holds out formal law, especially international human rights law, as a necessary corrective to the oppression assumed to be inherent in certain traditional social structures. ${ }^{120}$

$90 \%$ of whom were girls, headed more than 45,000 homes in Rwanda after the genoeide. Laurel L. Rose, Orphans' Land Rights in Post-War Rwanda: The Problem of Guardianship, 36 Dev. \& Change 911,919 (2005) [hereinafter Rose 2005]. Even less than adult women, these orphan girls have virtually no ability to maintain any land rights and live in constant risk of food and housing insecurity. See id. at 919-20; Warah, supra note 102.

115. HRW, StrugGLING To SuRvive, supra note 61, at 11-12.

116. In sub-Saharan Africa, Burkina Faso, Malawi, Mozambique, Niger, South Africa, Tanzania, Uganda, and Zimbabwe have all enacted legislation affirming women's access to land rights. Urban Shelter, Women's Property Rights 34, http://www.unhabitat.org/istanbul+5/34.pdf. Rwanda's Succession Law, supra note 19, despite its anti-discrimination language, has not effectuated women's equal access to land.

117. See, e.g., HRW, SURviving the Struggle, supra note 61, at 11-12.

118. Rose 2004, supra note 24, at 237.

119. See Celestine 1. Nyamu, How Should Human Rights and Development Respond to Cultural Legitimization of Gender Hierarchy in Developing Countries?, 41 HARV. INT'L L.J. 381, 381 (2000).

120. For an archetypal example of this perspective, see, for example, Susan Muller Okin, Is Multiculturalism Bad for Women?, in Is MUlTICULTURALISM BAD FOR WOMEn? 12 (Joshua Cohen et al. eds., 1999) ("[M]ost cultures are suffused with practices and ideologies concerning gender . . . [that] substantially limit the eapacities of women and girls of that culture to live with human dignity equal to that of men and boys."). Scholars like Okin tend to see international human rights as a necessary intervention into "culture." 
Celestine Nyamu challenges this view. She argues that "contemporary perceptions of cultural norms" rather than culture itself, work in tandem with "formal institutions and processes" to justify practices that burden women or privilege men. ${ }^{121}$ In Kenya, as in Rwanda, women in many ethnic groups have historically been disallowed from inheriting land. Rather than protecting women from local-customary restrictions on their inheritance rights, formal Kenyan land law instead demonstrates a comparable bias against women. ${ }^{122}$ In embracing particular articulations of local custom and misconstruing them as immutable characteristics of culture, formal law has codified women's marginalization. ${ }^{123}$ Nyamu's analysis suggests that formal law and local-customary law can and do work in tandem to the disadvantage of vulnerable members of society-for example, women in a society that has historically not conferred gender-neutral inheritance rights. A custom- or culture-only explanation for gender injustice denies the role formal law in Kenya has played in perpetuating traditional structures of social stratification.

Culture is not, however, a static force: just as formal law adapts and evolves, so too does culture. Nyamu points out that local cultural values might provide a mechanism for promoting rather than diminishing gender justice. ${ }^{124}$ She offers an example from the Makueni District of eastern Kenya, where a communally shared desire to protect the material wellbeing of unmarried daughters has superseded traditional cultural norms that oppose daughters' inheritance rights. The people of this region have accepted women's new formal legal inheritance rights because "overarching principles of providing sustenance and taking responsibility for every child ... qualify[] the conventional notion that male children are the only ones entitled to their families' property."125

In some aspects, Rwandan culture has already demonstrated remarkable mutability regarding new roles for women. Following the genocide, women established hundreds of local and national organizations dedicated

121. Nyamu, supra note 119 , at 411 .

122. See, e.g., Human Rights Watch, Double Standards: Women's Property Rights VIOLATIONS IN KENYA, 10 (Mar. 4 2003), available at http:/www.hrw.org/reports/2003/ kenya0303/kenya0303.pdf\#search=\%22Double $\% 20$ Standards $\% 3 \mathrm{~A} \% 20$ Women $\%$ E2 $\% 80 \% 99 \mathrm{~s} \% 20$ Prop erty $\% 20$ Rights $\% 20$ Violations $\% 20$ in $\% 20 \mathrm{Kenya} \% 22$ (noting that Kenyan women are $80 \%$ of the country's agricultural labor force but after a national land registration campaign were revealed to comprise only $5 \%$ of all registered landholders).

123. See Nyamu, supra note 119, at 400-01, 405 (arguing that "dominant articulations of culture [are not necessarily] accurate representations of a community's way of life" and describing "the active role that the state apparatus plays in defining culture").

124. Id. at 382 (suggesting that "[i]n a plural legal setting . . local customary institutions, present both opportunities and setbacks in the struggle for gender equality" and that gender justice advocates "must appropriate positive openings" that these institutions present).

125. Id. at 415 . 
to reconciliation and development. ${ }^{126}$ They took on new civic leadership roles in their communities. ${ }^{127}$ As single mothers, they sustained their families and adopted 500,000 war orphans. ${ }^{128}$ In 2004, women comprised 49\% of Rwanda's National Parliament, compared to a worldwide average of approximately I 5\% female representation in national legislatures. ${ }^{129}$

Rwandans have accepted increasingly visible roles for women in political and civic life, demonstrating Nyamu's thesis that, faced with particular circumstances, an adaptive culture can open itself up to new opportunities for women that did not previously exist. Accordingly, my intent in assessing Rwanda's failure to protect women's land rights is not to critique Rwandan culture as a static force that oppresses women. It is true that under local-customary law Rwandan women have not historically enjoyed the right to land. But the above examples demonstrate cultural fluidity and a willingness to accept women's increasing power in Rwandan communities. I argue that both formal and local-customary law can be adapted to ensure that Rwandan women enjoy equal land rights to men, in turn promoting greater stability for Rwanda's many women-headed families. In the context of land rights, the formal and local-customary mechanisms of Rwanda's parallel legal systein have so far failed to meet Rwandan women's changing needs. But while Rwanda's formal and

126. See Hamilton, supra note 112. Some examples of such organizations include Avega (a support group for genocide widows and rape survivors), Association for Rwandan Women's Solidarity, and Pro-Femmes (a collective focused on peace and development through women's empowerment). For a list of these and other organizations, see PeaceWomen, Women, Peace, and Security Contacts: Rwanda, http://www.peacewomen.org/contacts/africa/rwanda/rwa_index.html (last visited Apr. 1, 2006). Women's agricultural collectives are also providing women with greater shared power to demand fair prices for their crops, enabling them to provide for their families. See, e.g., Beatriz González, Rwandan Cooperative Shows Reconciliation Needed To Draw Refugees Home, UNHCR, Feb. 8, 2006, http://www.unher.org/cgi-bin/texis/vtx/ncws/ opendoc.htm?tbl=NEWS\&id=43ea0ced4 (discussing the market success of the Abahuzamugambi farming association, the membership of which is overwhelmingly female). The association's founder says that the organization "'has given to those women affected in one way or another by the war new reasons to live. I have three teenagers at home whose studies I can afford now, even if the money is still very little." Id.

127. OSAGI, supra note 113 , at 5 (noting that Rwandan women became community leaders and financial providers following the genocide).

128. See Jodi Enda, Women Take the Lead in Reconstruction of Rwanda, WOMEN's ENEws, http://www.womensenews.org/article.cfm/dyn/aid/1602/context/cover/ (last visited May 9, 2005).

129. Gumisai Mutume, Women Break Into African Politics, http://www.peacewomen.org/ news/Rwanda/May04/Womeninpolitics.html (last visited May 9, 2005). The astonishing level of political representation resulted from a combination of factors: a constitutional provision that sets aside twenty-four of eighty lower-house seats for women; women's success in gaining fifteen additional seats beyond those statutorily mandated; the creation of a system of women's councils that operate at the cellule level; and a triple balloting system that guarantees women a percentage of seats at the préfecture level. Id.; OSAGl, supra note 113, at 9-11. In achieving this level of gender balance in its national legislature, Rwanda "outrank[s] even the Scandinavian countries." Noeleen Heyzer, Executive Dir., UNIFEM, Speech Before the Summit on the Americas: Women's Participation and Leadership: Vital to Democratic Governance, (Jan. 13, 2004) (Mexico), available at http://www.unifem.org/ news_events/story_detail.php?StoryID=168. 
local-customary laws do not currently bolster women's land rights, they are dynamic forces with the potential to empower rather than subordinate. ${ }^{130}$

Particularly given the primacy of land to subsistence in a region that is still predominantly agrarian and pastoral, meaningful land regulation in the Great Lakes region must engage with traditional or local-customary land use patterns as well as the impact of colonization and ensuing decades of struggle. ${ }^{131}$ Despite the indelible influence of modernization and globalization in the Great Lakes, local-customary land use regulations persist in tandem with newer formal regulations based on state constitutions and statutes. Instead, the formalization of local-customary land access in Rwanda and throughout the Great Lakes region, along with "contemporary perceptions of cultural norms, official appropriation of culture to justify male ownership, and official commitment to private individual ownership," have increased risks that vulnerable members of Rwanda's population, including women and returning people, will face further marginalization. ${ }^{132}$

In not regulatimg its parallel legal structure so as to provide equitable land access for all Rwandans, the new Rwandan government has failed to respect, protect, and fulfill the land rights of its most vulnerable members, who continue to experience land and shelter insecurity. The Rwandan government deserves censure for affirmatively (through legislation and policy choices that have severely disrupted land stability) and by omission (in not bolstering formal law protections against capricious application of localcustomary law by low-level officials) impeding its development efforts and violating its legal and custodial duties to its citizenry.

At the same time, a shortage of both land and material resources significantly hinders the government's ability to meet the land needs of its people in the aftermath of a brutal genocide and mass displacement. The I994 genocide culminated thirty-five years of war. To establish a lasting peace, Rwanda needed legal and political structures capable of addressing the country's pressing governance challenges, including how to resolve land disputes equitably. With many official records destroyed, the former government debilitated, 800,000 people murdered, and four million more in exile or internally displaced, Rwanda would have benefited-as the former Yugoslavian republics did-from active involvement in the peace process by neutral international bodies such as the United Nations. Though the U.N. Security Council acted quickly after the genocide to establish the International Criminal Tribunal for Rwanda (ICTR), with jurisdiction over

130. See Nyamu, supra note 119, at 401 ("Attributing gender hierarchy to a vague notion of culture masks the role played by formal legal institutions in creating those conditions.").

131. Cf. HugGins et AL. 2005, supra note 35, at 5 .

132. Nyamu, supra note 119 , at 411 . Nyamu explains that "contemporary cultural perceptions of men as the proper authority in land matters and ... narrow, individualistic conceptions of ownership in the formal legal regime" in addition to male bias in land registration have "weaken[ed] the position of women in relation to property officially held by their husbands and male relatives." $I d$. at 396. 
crimes against humanity and genocide, ${ }^{133}$ the international community did not engage in the creation of a Rwandan peace agreement. Even if the new Rwandan government had actually devised practicable mechanisms for resolving land disputes without international support, it still would have benefited from multi-national involvement and support, which would have smoothed Rwanda's transition back to stable civic life, with positive effects on land security for women and returning people, and consequently on its goal of building a lasting peace.

The international community is therefore at fault, along with the Rwandan government, for not providing more effective legal and material assistance to Rwanda as it struggled to achieve peace. In other post-conflict settings, international collaboration has germinated effective legal structures for resolving land disputes in culturally appropriate ways, demonstrating that international involvement has the potential to facilitate recovery in volatile states. The next Part explores successful examples of such international involvement in peace processes in Sri Lanka and the former Yugoslav republics.

III

Resolving Post-Conflict LAND Disputes

THROUGH INTERNATIONAL COORDINATION

Though the focus of this paper is not to explore in depth the reasons for the lack of international involvement in Rwanda's peace process, I offer the following analysis of land-dispute resolution mechanisms in Sri Lanka and the Balkans-which were very much the fruits of coordination between domestic and international actors-both as land-dispute models that might guide Rwanda's present land reform process and as examples of the international community's willingness in other contexts to provide the very type of structural and legal assistance Rwanda required. Although the historical circumstances out of which these comparative models arose differ from those in Rwanda, they nonetheless provide useful frameworks with which to analyze how a just and efficacious model for settling land disputes could be implemented in Rwanda.

\section{A. Sri Lanka: Government-Supported Community Mediation Boards}

Sri Lanka is emerging from two decades of civil war between the government and Tamil separatists. ${ }^{134}$ As in Rwanda, the historical origins

133. See S.C. Res. 955, U.N. SCOR, 49th Sess., 3453d mtg., U.N. Doc. S/Res/955 (Nov. 8, 1994).

134. For a brief overview of the history of armed conflict in Sri Lanka, see UNHCR, Background Paper on Refugees and Asylum-Seekers From Sri Lanka 9-21 (2004). My discussion of Sri Lankan property dispute resolution is limited to policies implemented before the 2004 tsunami displaced over one million Sri Lankans. Relief Web, Sri Lanka: Post-Tsunami One Year Report (Dec. 31, 2005), http://www.reliefweb.int/rw/RWB.NSF/db900S1D/RMO1-6LK7RU?OpenDocument. 
of the conflict are rooted in a complex web of socio-economic and ethnic tensions. ${ }^{135}$ After a 2001 cease-fire between the government and the Liberation Tigers of Tamil Eelam (LTTE), the two main parties to the conflict engaged in a series of peace talks that were suspended in 2003 but have sirice resumed. ${ }^{136}$ The many years of civil war have caused massive internal displacement in Sri Lanka, affecting an estimated total of 800,000 people. ${ }^{137}$ Before the 2004 tsunami, 400,000 Sri Lankans were internally displaced, the high number resulting in part from increasing rates of return to Sri Lanka following the cease-fire. ${ }^{138}$

Sri Lanka has responded with a community mediation plan that utilizes local mediation boards, a free legal aid program, and a national human rights commission to resolve property disputes arising out of the Accelerated Resettlement Program. ${ }^{139}$ A National Mediation Boards Commission oversees the 218 local mediation boards, which provide free mediation services for disputes over movable and immovable property, contracts, and other issues. ${ }^{140}$ Five members, three of whom must previously have held judicial office in Sri Lanka's higher courts, comprise each board. The boards can reject cases they determine to require judicial resolution in the courts. Mediators are carefully selected and trained, pursuant to the Mediation Boards Act. ${ }^{141}$ The U.N. 1nter-Agency 1DP Working Group coordinates between the Sri Lankan government, UNHCR Sri Lanka, and UNHCR 1ndia, where tens of thousands of Sri Lankan refugees live in U.N.-run camps.

The mediation boards have resolved over 500,000 cases since $1990 .^{142}$ U.S. Agency for 1nternational Development (USAID) credits the program's success to numerous factors, including: (1) the "cultural fit of mediation

135. See UNHCR's Programme for Internally Displaced Persons in SRi Lanka, Report of A JoInt APPRAISAl Mission by THE UK DEP'T FOR INT'L Dev. AND UNHCR 3 (2002) (prepared by Nicola Jenns et al.) [hereinafter Jolnt APPRAISAL RePORT].

136. See Background Paper, supra note 134, at 19-21; UNHCR Briefing Notes, Sri Lanka: Resumption of Talks (Jan. 31, 2006), http://www.unhcr.org/cgi-bin/texis/vtx/news/ opendoc. htm?tbl=NEWS\&id=43df458f4\&page $=$ news.

137. Background Paper, supra note 134, at 50.

138. Id. at 51,55 .

139. For more information on the Accelerated Resettlement Programme and refugee repatriation, see Bulletin, U.N. Inter-Agency IDP Working Group, Durable Solutions Progress Report No. 10 (2003), available at http://www.peaceinsrilanka.org/insidepages/RRR/UNHCR/UNHCR10.asp.

140. Global IDP Project, Land and Property Rights of Internally Displaced Persons 59 (2003), http://www.cpalanka.org/research_papers/Land_and_Property_Rights_of_IDPs.pdf. The Accelerated Resettlement Programme seeks to resettle IDPs and refugees, who mostly live in camps in India.

141. Mediation Boards Act, No. 72 of 1988, as amended by Act, No. 15 of 1997, http://www.justiceministry.gov.lk/MEDIATION\%20BOARDS\%20ACT,\%20NO.\%2072\%200F\%201 988.htm (last visited May 15, 2006).

142. U.S. Agency for International Development (USAID), Alternative Dispute Resolution Practitioners' GuIDE 96 (1998), http://www.usaid.gov/our_work/ democracy_and_governance/publications/pdfs/pnacb895.pdf. 
with established social norms," such as the Sri Lankan tradition of asking a counsel of elders to resolve disputes and a religio-cultural preference for consensus rather than adversarial proceedings; ${ }^{143}(2)$ a clear legal structure and jurisdiction; ${ }^{144}$ (3) a perception that mediators are highly qualified and impartial; ${ }^{145}$ and (4) effective community outreach by the government to publicize the boards and encourage their use. The mediation boards achieve a settlement rate of nearly $65 \%{ }^{146}$ A clear procedure for appealing the boards' rulings ensures that participants have access to judicial resolution when mediation proves ineffective. The program, which costs the Sri Lankan government less than $\$ 500,000$ (U.S.) annually, ${ }^{147}$ enjoys high satisfaction and compliance rates and has significantly reduced court delays for other parties. 148 USAID concludes that "the Sri Lankan mediation boards have been incredibly successful at providing low cost, accessible justice to a majority of Sri Lanka's rural poor." 149 One notable shortcoming of the program, however, is the underrepresentation of women, who comprise just $2 \%$ of all mediation board chairs and $10 \%$ of all mediators. ${ }^{150}$

\section{B. Annex VII of the Dayton Peace Accords: Enforcing Private Property Rights in the Balkans Through Formal Adjudication}

By 1995, at the end of the four-year war between the former Yugoslavian republics, fewer than $45 \%$ of Bosnians remained in their original homes. ${ }^{151}$ Promulgated by the republics, the European Union, and the United States, the Dayton Peace Accords solidified the end of hostilities between the new Republic of Bosnia and Herzegovina, the Federation of Bosnia and Herzegovina, and the Republika Srpska. ${ }^{152}$ Annex VII to the Dayton Accords established a special tribunal to hear property claims arising out of the war. ${ }^{153}$ Article 1, Section One of Annex VII

\footnotetext{
143. Id. at 101-02.

144. Id. at 101 .

145. Id. The impartiality of the boards is further guaranteed by a national monitoring and evaluation poliey. Id. at 103-04.

146. Id. at 98 .

147. USAID, Alternative Dispute Resolution Practitioners' Guide, supra note 142 at 98.

148. Id. at 96 .

149. Id. at 109.

150. Id. at 99 .

151. Hans Das, Restoring Property Rights in the Aftermath of War, 53 1NT'L \& COMP. L.Q. 429, 432 (2004).

152. General Framework Agreement for Peace in Bosnia and Herzegovina, Bosn. \& Herz., Dec. 14, 1995, U.N. Doc. A/50-790-2/1995/999 (1995), 35 I.L.M. 75 [hereinafter Dayton Aceords].

153. Annex VII, Chapter II, art. XI ("The Commission shall receive and decide any claims for real property in Bosnia and Herzegovina, where the property has not voluntarily been sold or otherwise transferred since April 1, 1992, and where the elaimant does not now enjoy possession of that property. Claims may be for return of the property or for just compensation in lieu of return.") For a summary of the Dayton Aceords and the Security Council's establishment of the International Criminal Tribunal for the Former Yugoslavia, see Mark W. JANIS \& John E. Noyes, InTernational Law: Cases and COMMENTARY 479 (1997).
} 
announces the right of "[a]ll refugees and displaced persons ... freely to return to their homes of origin ... to have restored to them property of which they were deprived in the course of hostilities... and to be compensated for any property that cannot be restored to them." Article VII creates the Commission for Displaced Persons and Refugees (CDPR), which adjudicates land disputes between returning people and present occupants. The CDPR also has authority to regulate the value of real property, to effect transactions, and to award compensation. ${ }^{154}$ Successful claimants can seek return of their property or fair restitution. ${ }^{155}$ In contrast to the communal mediation approach adopted in Sri Lanka, Annex VII emphasizes adjudication and private title.

Three international experts, four national experts appointed by the Federation of Bosnia and Herzegovina, and two national experts appointed by the Republika Srpska comprise the CDPR, which must respect, but is not bound by, the domestic laws of the three republics. Authority to implement the Commission's orders resides with domestic organs that are obliged to "respect and implement its decisions expeditiously and in good faith." ${ }^{156}$ Research by Hans Das suggests that this designation has promoted enforcement of CDPR decisions because "[w]ell-defined procedural steps together with strict deadlines make it possible for the international community to better monitor the implementation process." 157

Another innovative aspect of the Annex VII model is its supportive approach to evidence collection, a vital accommodation for the one-third of claimants appearing before it who lack proof of their former property rights. ${ }^{158}$ Written evidence is required to support a claim before the Commission, but claimants need only present all written evidence available to them, in contrast to the typical standard in international tribunals of "proving the facts relied on to support a claim." 159 Other tribunals might relax the burdens of persuasion for claimants who cannot prove all the facts necessary to support their claims. ${ }^{160}$ Under Annex VIl the burdens remain constant; claimants instead receive assistance in collecting evidence that will help them meet their burden of proof, increasing the tribunal's

154. Annex VII, supra note I53, art. XI, art. XIV.

155. Id., art. XII, $\S 2$. Das explains that in actuality, rather than awarding restitution, successful claimants receive confirmation of their pre-war interests that they can then transact. Das, supra note I5 1, at 433. In his article, Das refers to the CDRP by the name Commission on Real Property Claims of Displaced Persons and Refugees, or CRPC.

I56. Annex VII, supra note 153, art. VIII.

157. Das, supra note 151 , at 440

I58. Id. at 438 .

159. Id.

160. See id. at 439 ("The Claims Resolution Tribunal for Dormant Accounts ... has set a relaxed standard of 'plausibility' for all claims. The United Nations Compensation Commission, created after the Iraqi invasion and occupation of Kuwait, established relaxed standards of evidence for certain categories of claims."). Das notes that relaxing the evidentiary burdens risks fraudulent claims. Id. 
legitimacy in the eyes of all parties. Annex Vll authorized the CDPR to initiate its own process of evidence collection and verification when a claimant was unable to present sufficient evidence herself; a staff of 400 supported the CDPR's evidence collection project. ${ }^{161}$

Within its first two years, the CDPR arbitrated 6,000 property claims. ${ }^{162}$ Under Annex VII, the UNHCR has overseen the return of 907,000 refugees to their homelands. ${ }^{163}$ The restitution fund Article XIV mandates never materialized, but the CDPR has instead enacted programs to promote a "secure, transparent and sustainable property market," providing compensation either between parties when possible or otherwise issuing a certificate indicating the value of a claimant's loss, which operates as currency in the real property market. ${ }^{164}$ Though claimants may not be able to enforce their claim to a specific piece of property, Das explains that the Commission's "decisions constitute and are nowadays generally recognised as irrefutable proof of title... [which is] valuable for those wishing to sell, buy or exchange on the market."165

Despite this success, critics suggest that the CDPR suffers from flaws inherent in the treaty. Madelyn Shapiro has argued, for example, that Article XIV is internally inconsistent, lacks a specific timeline, and suffers from ineffective implementation due to the absence of any authoritative mechanism to enforce its decisions. ${ }^{166}$ Due to these weaknesses, nationalist parties have been able to gain power, discouraging high rates of ethnicminority returns and impeding the emergence of a stable multi-ethnic state. ${ }^{167}$

ln addition, Annex VII does not address women's special obstacles in seeking property restitution. Kerstin Grebäck and Eva Zillén assert that Annex VII, and the Dayton Accords more generally, lack adequate protections for women returnees. ${ }^{168}$ They fault Annex VII for not articulating

161. Id. at 436,438 . As a comparison of resource allocation by the international community, in 2004, the total staff for the ICTR, including judges, lawyers, clerks, investigators, secretarial staff, translators, and security for the three trial chambers in Arusha and the appeals chamber in The Hague, numbered 1,042. ICTR, General Information, http://www.ictr.org (last visited May 9, 2005).

162. Madelyn D. Shapiro, The Lack of Implementation of Annex 7 of the Dayton Accords: Another Palestinian Crisis?, 14 AM. U. INT'L L. REv. 545, 549 (1998).

163. See U.N. Division for the Advancement of Women (DAW), Expert Group Meeting on "Peace Agreements as a Means for Promoting Gender Equality and Ensuring Participation of Women - A Framework of Model Provisions," Peace Agreements as a Means for Promoting Gender Equality and Ensuring Participation of Women, EGM/PEACE/2003/EP.2., at 13 (Nov. 10-13, 2003) (prepared by Kerstin Grebäck \& Eva Zillén) [hereinafter Grebäck \& Zillén]

164. Das, supra note 151, at 441-42.

165. Id.

166. See, e.g., Shapiro, supra note 162, at 566 ("Annex 7 places too much power in the hands of the parties. ... The apportionment of responsibility between three parties who have so recently becn at war with each other presents a significant risk of failure.").

167. Id. at 558-75.

168. See Grebäck \& Zillén, supra note 163. 
gender-specific affirmative rights: for example, the Annex does not specifically mention the return rights of widows and single women and does not require that any women sit on the CDPR. ${ }^{169}$ Grebäck and Zillén also argue that the provisions governing property return, in relying on domestic laws that "reflect traditional practices and customary norms whereby men are primary owners of land," disadvantage women's ability to reclaim or acquire land. ${ }^{170}$

Notwithstanding these shortcomings, Annex VII establishes a formal adjudication structure that has proven fairly successful in resolving competing claims to private property in the states within its jurisdiction. Its administrative, as opposed to adversarial, nature lends an efficiency lacking from traditional court-based models such as the special South African Land Claims Court, which conducts full adversarial hearings that tend to slow the pace of resolution, and the European Court of Human Rights, which has formally adjudicated property disputes arising out of refugee return to Turkey and Cyprus. ${ }^{171}$ The mixture of international and local participation in the CDPR helps ensure impartial but locally germane adjudication, and the incorporation of international and domestic law allows the commissioners to apply the best aspects of each.

\section{Applying the Sri Lankan and Baltic Models to Rwanda}

A version of the Sri Lankan community mediation model, with some adaptations, could help resolve Rwanda's land disputes at a low cost to the government. Unlike the adversarial nature of the dispute resolution mechanisms envisioned in Annex VII of the Dayton Accords, the mediation boards operate throughout the country, increasing accessibility to those without means to travel to an urban center. Because Rwanda has a similar cultural tradition of communal dispute resolution - the gacaca-Rwandans would likely respond positively to the mediation model's emphasis on compromise for the good of the whole. Rwanda might face greater challenges in finding qualified mediators than has Sri Lanka, which has higher literacy rates, but international organizations could assist in training those boards. The clear appellate procedure ensures access to the courts. In Rwanda, this appellate route would benefit from the provision of free legal assistance to indigent parties, similar to Sri Lanka's Legal Aid Programme. Finally, the model allows for a flexible application of formal and localcustomary laws, a flexibility that is vital given Rwanda's traditionally noncadastral system. Unlike Sri Lanka's program, however, any

169. Id. at 5 .

170. Id.

171. See, e.g., Loizidou v. Turkey, 1996-VI Eur. Ct. H.R. 2217; 23 H.R.R. 513 (upholding a Greek Cypriot's property-ownership claim against Turkey for property she had last inhabited twenty-two years earlier). 
mediation-board model in Rwanda must include a firm mandate for women's equal representation.

A Rwandan commission similar to the CDPR, with a specific mandate to adjudicate land disputes in a consistent manner and comprised of a multi-national team of trained jurists, would have minimized the ad hoc nature of land allocation following the civil war and genocide. The evidence assistance program would also have aided those who lacked proof of their land claims, though oral testimony would likely be the only evidence available in many cases.

While fairly successful in the Balkan context, however, the "restitution through adjudication" mechanism is not well suited to Rwanda's unique circumstances. Even with material support from international donors, supplying Rwandan commissioners would have been a challenge. ${ }^{172}$ The temporal remoteness of many returning people's claims, combined with Rwanda's land shortage, makes restitution a much less viable remedy for Rwanda than it was for the Balkan states, where refugees' departure was more short-term. The CDPR's alternative remedy of fair compensation is equally inapposite for an impoverished state that until 2004 lacked resources to provide free primary education to its citizens. Even if funds were available for financial compensation, money in hand would not solve a returnee's land and livelihood needs because Rwanda lacks any formal real estate market such as the one that absorbed the European returnees who received compensation or market waivers under the CDPR. Moreover, the concept of private title is historically alien to Rwanda, where people have traditionally only held usufructuary rights to state-owned land. While people need clear resolution of disputed claims, awarding private title would be inapposite. An all-or-nothing adjudication model also suggests a "victor" and a "loser," an implication that would not guide Rwandan society towards reconciliation after the genocide. ${ }^{173}$

I have presented these two alternative models to resolving land disputes in post-conflict regions to demonstrate four themes. First, international involvement in the development of a resolution apparatus and material support for its implementation significantly increase the likelihood of effective disposition of competing land claims. Second, rights education is crucial to ensuring that a population's most vulnerable members

172. Recall that as of 2003 Rwanda had only 236 judicial officers and 379 judges. Supra note 81 . Due to Rwanda's unique land tenureship patterns, a commission comprised only of foreigners would have been impracticable.

173. Criticism has been launched at both the ICTR as well as the Tutsi-predominated Rwandan government for charting a course of "victor's justice" in prosecuting genocide and related erimes. See, e.g., Rory Carroll, Genocide Tribunal 'Ignoring Tutsi Crimes,' Guardian, Jan. 13, 2005, available at http://www.globalpolicy.org/intljustice/tribunals/rwanda/2005/0113tutsicrimes.htm; MAMDANI, supra note 23 , at $266-73$ (discussing the imperative to contextualize the genocide and offering an alternative theory of "survivor's justice"). 
understand their legal entitlements and that they have access to institutional support to pursue their rightful claims. Third, representation of women and other vulnerable sub-groups promotes wider participation, fairer representation of various perspectives, and broader legitimacy. Finally, an effective resolution model should be culturally and historically responsive. In Sri Lanka, a community-based mediation system that allowed for compromise and group healing along with equitable resolution of land disputes met the needs of a communally oriented society emerging from decades of civil war. In the Balkans, a more adversarial process was effective when the competing claims were to recently abandoned property and when those societies were already familiar with a trial-based approach to dispute resolution.

The most effective structure for Rwanda must likewise meet the specific needs of a still agrarian, still poor society that continues to grapple, as does Sri Lanka, with a decades-old history of violence. In addition, Rwanda's historic and deeply rooted custom of community-based adjudication and the fragility of its under-resourced legal system suggest the potential strength of a non-adversarial, group-based approach to resolving competing land claims. The land reform policies undertaken by the Rwandan government since I994, however, have instead fostered further dissension, prolonging Rwanda's road to recovery.

IV

Analysis of Rwandan Land Policies Since 1994

Without a formal peace process in place or a specific legal mechanism to guide the return of millions of people after 1994, adjudication of land disputes in Rwanda has been inconsistent, to the disadvantage of the country's most vulnerable members. The ministerial orders discussed in Part I only created further confusion. The most recent statistics available indicate that as of 2005, five years after the United Nations stopped classifying landless Rwandans as IDPs, at least 650,000 people inside Rwanda remain unsettled. ${ }^{174}$ The government's land policies, targeted at the general population rather than returning people, have only compounded Rwandans' land insecurity. The NHP, the Succession Law, and the Land Use and Management Law do not add stability to Rwanda's land crisis and specifically burden Rwandan women, whose land security is vital to economic development. Instead, they demonstrate Nyamu's observation that formal law can reify rather than check the oppressive potential of local-customary law when it does not prioritize women's unique needs.

174. Ensuring Durable Solutions, supra note 63, at 10-11. 


\section{A. National Habitat Policy}

In December 1996, the Rwandan government announced the implementation of the NHP, through which it has tried to resettle the country's rural inhabitants into government housing settlements, or imidugudu. ${ }^{175}$ Because rural dwellers in Rwanda have traditionally created scattered homesteads throughout the country's many hillsides rather than clustering in villages, the NHP poses a substantial upheaval to the $94 \%$ of Rwandans living outside the country's two small urban centers. ${ }^{176}$ The government presented the NHP as a response to the sudden influx of new caseload returnees arriving from Tanzania at the end of $1996 .{ }^{177}$ The arrival of 1.3 million refugees within a few weeks ${ }^{178}$ would have justified dramatic temporary measures, including the creation of temporary settlements for returnees. The NHP, in contrast, is a long-term reorganization plan, equivalent to forced, permanent resettlement of a large segment of Rwandan society. ${ }^{179}$

175. See République Rwandaise, Ministère des Travaux Publics, Politique Nationale de l'Habitat, Dec. 1996, p. 20, cited in HRW, Uprooting the Rural Pook, supra note 13, at 11 n.17. Imidugudu, the plural form for one umudugudu, can be described as planned rural villages.

176. HRW, UPRooting The RuRal Poor, supra note 13, at 1.

177. See Republic of Rwanda, Ministerial Order No. 01/96 of Sept. 23, 1996, Regarding the Temporary Management of Land Property, cited in HRW, UPROOTING THE RURAL POoR, supra note 13 , at 9 n.11.

178. Id. at 8 .

179. See id. at 11 (pointing out that the ministerial order introducing the NHP discusses permanent goals such as land redistribution, the creation of non-agricultural jobs, and combating urban migration); Huggins \& Musahara, supra note 49, at 6 (noting the continued implementation of rural reorganization and villagization).

The UNHCR has firmly rejected state-sponsored displacement. In 1997 it convened an Expert Seminar, which promulgated a set of guidelines for protecting the human rights of people subject to forced eviction. See Secretary-General, Report of the Secretary-General on the Expert Seminar on the Practice of Forced Evictions, Annex, delivered to the Economic and Social Council, U.N. Doc. E/CN.4/Sub.2/1997/7 (July 2, 1997) [hereinafter Eviction Guidelines]. See also Guiding Principles on Internal Displacement, U.N. Doc. E/CN.4/I998/53/Add.2 (Feb. 11, 1998) and E/CNA/1998/53/Add.2* (Oct. 16, 1998) (reprint for technical reasons) [hereinafter Internal Displacement Principles]. The Eviction Guidelines require that when evictions do occur, the state must provide alternative land or housing, which would arguably oblige Rwanda to providc safe and habitable housing to residents evicted as the result of adjudication of competing land claims and to create conditions in which evictees and resettled returnees alike can earn a living and meet their children's material and educational needs. See id, paras. 26-28. The Eviction Guidelines' recommendation that a "full and fair public hearing" precede any state-approved resettlement action, in addition to monitoring by the UNHCR, would be well taken in Rwanda. See id., paras. 28-29. These guidelines, while not mandatory authority, are persuasive in their application of fundamental human rights principles to forced evictions.

The Internal Displacement Principles similarly require that states protect IDPs by providing humanitarian assistance and special guardianship for vulnerable groups and individuals, including children and female heads of household. See Internal Displacement Principles, principles 3(1), 4(2). States bear a duty to avoid displacement, which is unjustified unless intended to protect the health and safety of civilians from violence or natural disasters. When a state does pursue displacement, as the new Rwandan government did through the NHP, it must first seek "free and informed consent," with access to meaningful judicial review, and provide proper accommodation, security, and humanitarian assistance. The Eviction Guidelines assign states the ultimate responsibility to "secure by all 
Since the NHP's implementation, at least 600,000 people have been relocated to 180 imidugudu throughout the country. ${ }^{180}$ The program demonstrates the government's efforts to resettle the entire population, and not just returning people. The government claimed the Arusha Accords as its legal authority for the program, but that document only requires the state to provide temporary settlements for returnees until they can be permanently relocated to the site of their preference. The NHP went a step further in compelling returnees to settle permanently in state-provided imidugudu, in violation of their rights under the Arusha Accords and international refugee law to create a home in the location of their choosing. ${ }^{181}$ The government's insistence that returning new caseload returnees resettle in the imidugudu, even though they had abandoned their lands within the past ten years and were consequently not barred by the Arusha Accords from reclaiming their lands, further supports the conclusion that it intends the NHP as a permanent rather than temporary policy. ${ }^{182}$ Finally, the emphasis in the Land Use and Management Law of 2005 on villagization and urbanization suggests that the NHP reflects a broader governmental goal of transition to a commercial economy by restructuring traditional land tenureship patterns. ${ }^{183}$

Imidugudu residents have expressed dissatisfaction with their quality of life in the settlements, including concerns about security, hygiene, food scarcity, lack of health facilities, and remote water sources. ${ }^{184}$ Human Rights Watch reports:

Some homeowners were forced to destroy their houses before moving. Lacking the necessary resources to build new houses,

appropriate means, including the provision of security of tenure, the maximum degree of effective protection against the practice of forced evictions for all persons under their jurisdiction . . particularly female-headed households and other vulnerable groups." Eviction Guidelines, Annex para. 9. The forced dislocations also violate non-returnces' rights under the ICCPR and the ICESCR to freedom from state interference with their right to home and family life. See supra notes 77-78.

180. Global IDP Database, supra note 104, at 24.

181. See supra note 66 and accompanying text (discussing the requirements of the Arusha Accords); supra note 179 (discussing international human rights legal norms on the right of return and resettlement); see also HRW, UPROOTING THE RuRal POOR, supra note 13, at 46-47 (discussing the Arusha Accords and noting that they established returnees' "inviolabl[e tenure rights] but [] in effect guaranteed the same land to two different parties .... [and] recommended that returnees not reclaim any property left more than ten years before ....").

182. See Ensuring Durable Solutions, supra note 63, at 10 (noting that the Hutu returnees to Ruhengeri and Gisenyi provinces were resettled in the imidugudu even though they would not have encountered many competing land claims due to the low number of Tutsi returnees in the area).

183. See also Land Use and Management Law, supra note 1, Chap. 111: Management, Organisation, \& Exploitation of Land.

184. HRW, Uprooting THE Rural PoOR, supra note 13, at 21. Disease outbreaks are common in the imidugudu. Some are located more than twenty kilometers from a health facility. Three years after the implementation of the NHP, only $20 \%$ of the settlements had on-site water sources. Id. These conditions led one resident to exclaim, "They said that life in the umudugudu would be extraordinarywith water, school, electricity, a good road! But here we are under plastic sheeting. They promised houses but 1 see nothing. You find me under this sheeting with holes in it that the rain comes through." Id. at 22. See also Ensuring Durable Solutions, supra note 63, at 12. 
hundreds of thousands of people lived in temporary shelters made of tree limbs, leaves, and pieces of plastic. Some cultivators were forced to cede their fields to serve as settlement sites. Many village residents had to walk miles further each day to reach their fields or sources of water and firewood than when they lived in their previous homes. Difficulty in reaching fields and insecurity over land tenure resulting from villagization caused a decline in agricultural production, which was further cut by drought ... [and] serious food shortages threatened regions where villagization was most advanced. ${ }^{185}$

Additional challenges facing imidugudu residents include substandard shelters and sanitation and insufficiently sized plots, causing food insecurity and chronic malnutrition for children under the age of five. ${ }^{186}$

The NHP has worked to the particular disadvantage of Rwandan women, especially single and widowed women, who together head $59 \%$ of homes in the imidugudu. ${ }^{187}$ Unprotected by land laws and marginalized in the informal land market, many of these women, especially those with dependent children or orphans, were initially drawn to the imidugudu by the promise of housing and security. ${ }^{188}$ But because the NHP left wide discretion to local authorities to grant or deny land rights within the imidugudu, women often encountered the same obstacles to land rights and basic resources as they had outside the settlements. ${ }^{189}$ Human Rights Watch reports that women-headed families occupy the worst structures in the imidugudu and are located the farthest from vital resources. ${ }^{190}$ One woman, for example, reported a two-mile journey to get water. ${ }^{191}$ Single women also risk sexual coercion from male local officials anytime they seek assistance. ${ }^{192}$ Inadequate security in the imidugudu exposes women to sexual violence and the risk of HIV infection. In short, rather than ensuring the special protection of women, particularly single women with families, the NHP exposes them to further economic and physical danger.

Field interviews also indicate that the NHP has fanned further interethnic tension. Many non-returning people in Rwanda resent the resettlement programs and perceive the NHP as revenge by the Tutsi-dominated government against Rwanda's Hutu. ${ }^{193}$ The government's regionally

185. Human Rights Watch, Human Rights Developments: Rwanda, in Human Rights Watch WORLD REPORT $200 \mathrm{I}$ (2001), available at http://www.hrw.org/wr2k1/africa/rwanda.html [hereinafter HRW, WORLD REPORT 200I]. In addition to the devastation imposed on human life and dignity, the villagization program has led to severe deforestation. See Tiemessen, supra note 25 , at 8 .

186. Ensuring Durable Solutions, supra note 63, at 12-13.

187. HRW, UPRoOting The Rural Poor, supra note 13, at 57.

188. Id. at 57.

189. Id. at 57-60.

190. Id.

191. Id. at 57.

192. Id. at 59-60.

193. HRW, UPRooting The RuRal PoOR, supra note 13. at 62. 
disproportionate implementation might well contribute to this resentment: for example, $92 \%$ of the population in the majority Hutu Kibungo district has been forcibly resettled, compared with only $1 \%$ of the predominantly Tutsi Gikongoro area. ${ }^{194}$ The Policy has also flamed hostility between those who never left their homes and returnees who sought refuge outside Rwanda after the 1959 Hutu Power revolution. ${ }^{195}$ Because ethnicity defines this division, rcsentment against the NHP tends to evoke ethnicity-based resentment as well, once more in relation to struggles over land access and resource security. ${ }^{196}$ One woman explained to a field researcher that "here we are all Hutu," an articulation of widespread perceptions of unequal treatment in regards to land allocation. ${ }^{197}$

A government seeking to promote national recovery in the wake of catastrophic political and social upheaval should prioritize social stability and meeting the basic subsistence requirements of its people. Yet even as of 2005, the government was continuing to force resettlement into imidugudu, in violation of its people's rights. ${ }^{198}$ The NHP has actually increased landlessness rather than ameliorating Rwandans' land insecurity ${ }^{199}$ and has further hindered the ability of the country's most vulnerable groups to meet their basic subsistence needs.

\section{B. Matrimonial Regimes, Liberties and Succession Law}

Rwanda's Succession Law is simple in its proclamation: "All children, without distinction between girls and boys ... have a right to the partition made by their ascendants." 200 Title II of the Law extends equality of inheritance to widows, unmarried women without patrilineal siblings,

194. S. Takeuchi \& J. Marura, Agriculture and Peasants in Rwanda: A Preliminary REPORT 30 (Institute of Developing Economies, 2000). Some international aid workers have gone so far as to describe the application of the NHP in the northwest, where the government fears infiltration by Hutu insurgents from neighboring $\mathrm{DRC}$, as a campaign to depopulate the region. Global IDP Database, supra note 104 , at 21 .

195. See HRW, Uprooting the Rural Poor, supra note 13, at 62 ("One woman in the northwest .. . spoke bitterly of the order to destroy [her home]: 'People are very sad. This is an act of revenge. It is a vengeance. There is a local official who supposedly said "[Tutsi] left in 1959 and their homes were destroyed then. Why don't you want to destroy yours?" People see this as a subtle form of vengeance."').

196. See id. at 64 (noting competition for land in the imidugudu, large numbers of residents still living in grass-thatched shelters, and severe malnutrition).

197. Ensuring Durable Solutions, supra note 63, at 15.

198. Id. at 8-10 (describing the ongoing implementation of the villagization policy). See supra notes 76-79 and accompanying text and note 179 and accompanying text on Rwanda's obligations to meet human rights norms contained in the international treaties to which it is a party, including the right to shelter and to safe return.

199. HRW, Uprooting the Rural Poor, supra note 13, at 42 (noting that $66 \%$ of imidugudu residents are now landless, compared with $47 \%$ who were landless before moving to the imidugudu). Another $21 \%$ saw their land holdings decrease when they moved to the imidugudu. Id.

200. Succession Law, supra note 19, art. 43. 
and married women without siblings. ${ }^{201}$ The Law also establishes three matrimonial regimes: community of property, limited community of acquests, and separate ownership. ${ }^{202}$ Either spouse has authority to seek a modification of the couple's choice of regime..$^{203}$

The Succession Law takes a unique and vital step toward establishing women's ability to enjoy land rights on par with men, but the Law's provisions fall short of enabling women to enforce those rights. Articles 81 and 82 provide for the creation of local Family Councils of Succession that have significant authority to counteract the affirmative protections in Article 43. ${ }^{204}$ Under Article 51, which governs the partition of succession between children, a Council "shall determine the part of the patrimony to be earmarked for the raising of minors and the part to be shared between all the children of the de cujus." 205 This authority could interfere with a widow's ability to partition succession rights amongst her children according to what she thinks is in her family's best interests. ${ }^{206}$ Under Article 77, "where it is impossible to establish equal [partition] shares ... [a Council] determines the compensation to be given by the heirs who receive a share greater than their legal or testamentary share of the succession, for the benefit of the heirs who received a smaller share."

Article 70 allows a Family Council to allocate a decedent's holdings to his or her parents "when the widower or the widow does not fulfill his/her duty of assistance to the parents of the de cujus" and to decrease a surviving spouse's succession by three-quarters if he or she "fails to fulfill his/her duties to raise the children of the de cujus."207 No criteria are established by which to assess "failure." Even Article 43, with its explicit endorsement of women's inheritance rights, adds a qualifying limitation,

201. Id. arts. 43,70

202. Id. arts. 1-13.

203. Id. art. 19.

204. A Council of Succession forms when controversies in succession arise. Article 81 requires that a Council "shall include: the surviving spouse; a child delegated by the children of the deceased, where there are any who arc of majority age; a delegate of the family of the de cujus; a delegate of the family of the surviving spouse; a friend or a person of good behaviour appointed by the family of the surviving spouse; a friend or person of good behaviour appointed by the family of the de cujus." Id. art. 81.

205. Id. art. 51. De cujus is a legal term of art in French meaning "the deceased."

206. See Rose 2004, supra note 24, at 216 ("[E]ach Council of Succession is granted considerable powers to determinc the adequacy of an heir's care for the deceased before his or her death, the adequacy of an heir's care for the deceased's children, and the appropriateness of an heir's property transactions.").

207. Succession Law, supra note 19, art. 70(5)-(6). Article 70 further mandates that a childless spouse who remarries will forfcit onc-half of his or her inheritance from the decedent, with the other half going to the dccedent's heirs. A surviving spouse who subsequently gives birth to an illegitimate child forfeits one-half of his or her inheritance to the children of the de cujus. Article 70's language is rigorously gender neutral, but at least section $70(9)$ - on giving birth — seems directed primarily at women. 
"excluding those banished due to misconduct or ingratitude."208 This qualification could hinder the ability of women who have experienced sexual violence to inherit. ${ }^{209}$

Because women are still a majority of the population and statistically outlive men, ${ }^{210}$ these provisions limit the strict equality edict in Article 43. Additionally, women who do not qualify as "legal widows"-either because they entered into marriage through an informal common law arrangement or because they married without receiving a bride wealth-are susceptible to a determination of inadequacy. ${ }^{211}$ The willingness of the law to recognize succession rights only in the context of formal marriages, which are proven by the payment of a bride wealth, discriminates against those who cannot afford to comply with formal marriage requirements and indicates the government's willingness to enforce land rights only for women from a particular class background, with the effect of further disadvantaging the country's poorest and most vulnerable women. ${ }^{212}$

Article 91's prohibition against partitioning estates already sinaller than one hectare could also hinder women's ability to bequeath and inherit land because women tend to hold smaller plots. In the same way, a parent with a one-hectare plot would have to choose between his or her children rather than divide the plot between them, in which occurrence traditional biases against female inheritance might disadvantage daughters in such decisions. Finally, the restriction will prevent more plots from becoming available: fewer plots mean fewer opportunities for women and men to inherit. Though dwindling plot sizes present sustainability challenges, a per $s e$ restriction on small-plot alienability seriously disadvantages small farmers who need to provide for all their children. A resolution to the problem of shrinking single-user farms that allows a special exemption for women, particularly single heads-of-household, would better balance the potentially competing goals of maintaining viable plot size while ensuring women's access to land. For example, a single mother might be allowed to inherit a plot smaller than one hectare from her relatives, in recognition of her unique struggle to sustain her family. Another possibility would be allowing a similar exception to families who demonstrate a desire to share their land equally between male and female children, in recognition of the important goal of ensuring women's equal land access rights.

208. Id. art. 43.

209. See HRW, Struggling to Survive, supra note 61, at 11-12 (describing discrimination and abuse directed at female survivors of sexual assaults and rape).

210. UNFPA, Rwanda: Overview, http://www.unfpa.org/profile/rwanda.cfm (last visited May 9, 2005).

211. Catherine Newbury \& Hannah Baldwin, Profile: Rwanda, in Women and CIvIL War: IMPaCt, ORganizations, AND ACtion 34-35 (Krishna Kumar ed., 2001).

212. See, e.g., Rose 2004, supra note 24, at 210. 
Finally, the Succession Law fails to specify the outcome of a number of gender-specific potential scenarios, including whether a woman may inherit rights to land that her family purchased rather than inherited. Nor does it address whether and what rights to jointly held lands a woman retains after separation from her husband. The absence of mandatory guidelines in these gray areas leaves much discretionary legal space for the Family Councils to deny women's equal land rights.

\section{Land Use and Management Law of $2005^{213}$}

The Land Use and Management Law seeks to address a number of Rwanda's land regulation challenges, including land insecurity, underutilization, and unsustainable plot sizes. It emphasizes commercial exploitation through large-scale farms that produce cash crops and announces a consolidation goal that will force farmers with multiple, non-adjacent small plots to merge their holdings with others' ${ }^{214}$ It also creates an apparatus for the systematic registration of all land and for issuing private titles, in a dramatic shift away from the current system of state ownership. ${ }^{215}$ A full discussion of the dramatic changes the law imposes on rural Rwandans' ways of life would require an entire book. ${ }^{216} \mathrm{I}$ will focus here on the potentially significant impact of three major themes of the new law: the formalization and privatization of land tenure; the emphasis on consolidation, confiscation, and commercial exploitation; and the absence of express protections for vulnerable groups. In prioritizing profit maximization through a private-property, capitalist model, the law will likely further impoverish poor farmers and others who lack large landholdings. Unless the government simultaneously implements protective measures, these shifts could work to the detriment of Rwanda's rural poor, particularly women and other returning people who already experience land insecurity.

As a preliminary note, the Land Use and Management Law provides for the creation of national, provincial, and district-level land commissions to conduct land regulation. Mediation Committees operate at the secteur level. ${ }^{217}$ Article 8 requires that at each level of administration these authoritative bodies include women.

213. See Land Use and Management Law, supra note 1.

214. Many Rwandan farmers favor multiple small plots to maximize fertility. The average Rwandan farmer cultivates betwcen five and ten plots. Huggins \& Musahara, supra note 49, at 10.

215. See id. at 7-8; Rurangwa, supra note $48, \$ 3.2 .2$.

216. For example, the policy betokens dramatic environmental, economic, and cultural consequences for Rwanda. For a fuller discussion of these impacts, see Huggins \& Musahara, supra note 49 , at 7-8 (discussing, for example, the risk that small-plot holders will lose all land rights, the likely loss of biodiversity, and the thrcat of increasing poverty if the government fails to create sufficient non-farm economic opportunities); HuGGINS ET AL. 2005, supra note 35, at 5 ("Land rights, like all property rights, are socially-mediated entitlements. .. . This explains the tenacity of customary forms of tenure, despite the fact that statutory law has largely ignored them.").

217. Land Use and Management Law, supra note 1, art. 8. 


\section{Formalization and Privatization}

The Land Use and Management Law requires registration of all privately held land, ${ }^{218}$ a significant shift away from current land tenureship practice, in which only a fraction of all land is titled. ${ }^{219}$ The government believes that universal registration will

provide land users... with more certain rights and thereby promote investment of labour and capital in increased productivity, and the sustainable development and management of land resources. In addition land registration could extend the tax base in rural areas, and in any further development of further planned settlements or imidugudu. ${ }^{220}$

These goals indicate that the registration requirements are seen to serve the government's agenda to contmue to villagization as a means to freeing up more land for commercial exploitation.

As discussed below, this betokens a marked departure from traditional patterns of subsistence farming and disperse residential patterns. Liversage has pointed out that following the genocide and the collapse of localcustomary regulation, many Rwandans might actually prefer a system of private title over traditionally communal land ownership. ${ }^{221}$ Yet as he also notes, similar shifts to private title systems have had a detrimental impact on women's land security when implemented elsewhere in Africa. ${ }^{222}$

\section{Consolidation, Confiscation, and Commercialization}

The Land Use and Management Law grants the state the power to consolidate land "to improve rural land productivity" and delegates authority to establish procedures for consolidation to the Ministry of Agriculture. ${ }^{223}$ Articles 61 and 62 impose productivity requirements on tenants. ${ }^{224}$ Article 63 designates "the relevant authorities" as the promulgators of criteria by which to assess productivity. Articles 73 and 74 confer local and national-level officials with authority to impose sanctions on

218. Id. art. 30 .

219. See Rurangwa, supra note 48 , at 1 (noting that Rwanda presently "carries out limited land registration ... on a demand led hasis").

220. Id.

221. See Liversage, supra note 27 , at 11 (citing research by NGOs and the government). Liversage notes, however, that despite indications of openness to private title and individual ownership, "vestiges of communal tenure do appear to still exist in certain parts of the country, if only informally .... [such as] shared use of certain valley wetlands between villages." Id.

222. See id. at 13 (noting that "[r]esearch in other parts of Africa indicate that often the formalisation of land rights has led to the weakening of women's rights and access to land"). See also Nyamu, supra note 119, at 396 (noting that the imposition of title registration mechanisms often leads to registration in men's names and that joint registration between spouses is rare).

223. Land Use and Management Law, supra note 1, art. 20.

224. Article 61 requires "[t]he landowner, as well as any other user of the land . . to obey laws and regulations relating to ... better exploitation of the land." Article 62 requires "[a]ny person who owns land [to] use it in a productive way...." 
landowners who are not sufficiently maximizing productivity and to confiscate unexploited land. ${ }^{225}$ These measures indicate a clear policy shift towards commercial exploitation over subsistence farming, particularly in conjunction with evidence that the government intends to continue pursuing villagization.

Transitioning Rwanda's economy from subsistence agriculture to a cash-crop system in which large-plot owners hold private title will tend to disadvantage subsistence farmers and others who already lack land security. Jason Mosley has predicted that such a shift will encumber poorer farmers, noting that the implementation of a similar land-registration policy in Kenya forced small farmers to sell first their land, and then their labor to wealthier neighbors, contributing to increasing landlessness. ${ }^{226}$ The Rwandan government has explicitly indicated a preference for registering land to those "with a proven intention to develop and properly exploit the land" at the expense of those who already lack access. ${ }^{227}$ Because most of their agricultural work is subsistence-oriented, Rwandan women, already underrepresented among cash-crop farmers, will be less able than men to convince the government that they have the intention and the ability to exploit land for profit. In advocating a shift to a cadastral land regime, the Law poses a sea change to historic patterns of land regulation in Rwanda and threatens the very way of life of Rwanda's small-plot, subsistence farmers. It will particularly impede land security for women and other vulnerable groups, including the rural poor as a whole.

\section{Absence of Express Protection for Vulnerable Groups}

The Land Use and Management Law preserves Rwanda's parallel legal system, ${ }^{228}$ which, as discussed above, leaves women and other vulnerablc groups susceptible to land insecurity absent protective statutory fillers. ${ }^{22}$ But the new law offers no special protection for women and small-plot holders. Additionally, it defines "landless" people as "Rwandans who fled the country in 1959 or later and stayed outside the country for more than [ten] years." ${ }^{230}$ This textbook definition of old caseload refugees

225. Article 73 subjects a landholder to these penalties if the district land commission determines his or her lands are not "well managed and productively exploited."

226. Jason Mosley, Land Policy in Rwanda: Issues for UK Policy 3-4 (All Party Parliamentary Group on the Great Lakes Region and Genoeide Prevention, Working Paper No. 3, 2004). As noted above, after three years of the NHP, Rwandans' landlessness had increased while the size of land holdings for those who were not displaced tended to decrease. HRW, UPROOTING THE RURAL POOR, supra note 13, at 42 . These trends have increased rather than reduced the poverty of imidugudu residents. Id. Similarly, the government's decision to pursue large farms at the expense of delanding small-plot farmers is more likely to increase poverty than prosperity.

227. Huggins \& Musahara, supra note 49, at 12 (citing Section 5.1 of the National Land Policy).

228. Land Use and Management Law, supra note 1, art. 5, art. 7, art. 11.

229. See supra Part Il.B.

230. HugGins ET AL. 2005, supra note 35, at 31 (referring to $\S 5.1 .2 .3$ of the Draft Land Policy). 
who are predominantly Tutsi specifically excludes the Hutu new caseload refugees who left after the 1994 genocide. It also excludes IDPs, in spite of prohibitions in the guiding treaties against making rights contingent upon ethnicity or length of absence from one's country of origin. ${ }^{231}$ The Land Use and Management Law lacks any concrete protections for those most likely to lose their land through the redistribution, instead suggesting that farmers who lose their land rights can seek employment in the imidugudu. ${ }^{232}$ But off-farm employment opportunities are sparse in Rwanda and virtually nonexistent in the under-resourced imidugudu, where beer brewing comprises more than half of all non-farm economic activity. ${ }^{233}$ Nationwide, women hold only $20 \%$ of all non-farm jobs. ${ }^{234}$ Any policy that further increases women's landlessness must be accompanied by the immediate creation of other economic opportunities and skills training for non-farm jobs.

\section{Summary}

Rwanda clearly must seek land reform, possibly through dramatic measures. Its challenges in fashioning a workable model for land reform are twofold: resolving land disputes in a post-conflict environment still rife with inter-ethnic tension, and promoting economic development with insufficient land and material resources. Whatever reform strategies the government ultimately adopts must carefully address the needs of Rwanda's most vulnerable groups. In particular, the centrality of women's economic security to Rwanda's development requires that the government consider their unique needs in making legislative and policy decisions. Shifting away from its current subsistence-agriculture base may prove a necessary response to increasing population density and Rwanda's inevitable integration into the global economy. Yet the government's three major efforts to date- the NHP, the Succession Law, and the Land Use and Management Law-each impose significant changes to Rwandans' relationships to land and subsistence.

In forcing people to relocate against their will to under-resourced imidugudu, the NHP works against the best interests of Rwanda's rural

231. The OAU Refugee Convention does not distinguish between rights due long-time refugees and short-term refugees. See supra note 79. The Rwandan government is also bound not to discriminate on the basis of race or ethnicity. In addition to non-discrimination principles in the 1CCPR (art. 2.1), supra note 77, and the ICESCR (art. 2.2), supra note 78, the International Convention on the Elimination of all Forms of Racial Discrimination (CERD) prohibits, by act or omission, discrimination on the basis of race or ethnicity in the enjoyment of, among others, the rights to freedom of movement and residence within the state, the right to own property, and the right to inherit. 660 U.N.T.S. 195, art. 5, 5 1.L.M. 350 (1966)

232. See Huggins \& Musahara, supra note 49 , at $9-10$ (discussing the predicted effects of the National Habitat Policy).

233. Id. at 10. The National Habitat Policy also ignores the Twa.

234. Huggins \& Musahara, supra note 49 , at 13 
population and poses particular risks to women. The government should abandon this policy in favor of less disruptive strategies for sheltering its large landless population. The Succession Law is welcome in its attempt to bolster women's legal right to inherit but does not sufficiently protect those rights. The government should seek further legislative protection for women's land access rights and consider removing provisions in the Succession Law that confer broad discretionary power on the Family Councils. It should also establish a formal appeals process that gives women recourse to judicial resolution of disputes. Additionally, a continued public education campaign could help women fully understand and pursue their statutory rights. For example, in Sri Lanka the government, in conjunction with international aid organizations, undertook extensive efforts to educate its citizens about their rights. This built both awareness about and the legitimacy of the mediation boards. ${ }^{235}$ In Rwanda, however, many women are still ignorant of the Succession Law; others believe that because of land scarcity, only single women have a moral right to inherit land. ${ }^{236}$ The Land Use and Management Law overemphasizes commercial exploitation and fails to establish provisions to protect the land needs of small farmers, women, and Rwanda's many landless. Without affirmative efforts to ensure these groups' land security, the Land Use and Management Law's title-based system, especially in favoring large landholdings and commercial exploitation, could well work to their disadvantage.

\section{$\mathrm{V}$ \\ Concluding ObServations and Suggestions}

Conflict and mass migration over the last four decades have complicated the synchronization of local-customary, formal, and international law for Rwanda, with one consequence being perpetual land insecurity for its rural poor, particularly women and returning people. Despite some steps toward formal protection of women's land rights, many women continue to experience challenges in asserting claims. The NHP, the Succession Law, and the Land Use and Management Law have not created effective structures for fair allocation of land such that all Rwandans can enjoy basic protections such as the right to food, shelter, and livelihood, undoubtedly contributing to continued poverty and instability in Rwanda and neighboring states.

235. See, e.g., Jolnt Appraisal Report, supra note 135, at 9, paras. 24-25.

236. HugGins ET AL. 2005, supra note 35, at 22. Following the enactment of the Succession Law, local NGOs and Pro-Femmes, an umbrella organization of Rwandan women's groups, did engage in an educational campaign from September to December 2000. The Rwandan government also allocated five million Rwandan francs "to sensitize and create awareness of the law among women," in an important recognition that formal laws alone will not ensurc women's equal access to land rights. See Warah, supra note 102 . 
From 1994 to 1998, Rwanda received millions of returnees annually and continues to receive tens of thousands of returnees every year. In 2003 alone, 38,000 Rwandans repatriated, and another 13,500 repatriated in $2004 .{ }^{237}$ Given Rwanda's high poverty rate and the unavailability of unclaimed land, honoring the obligations to returning people prescribed by international law will inevitably compromise Rwanda's ability to meet the needs of people already within its borders. Rwanda must then strike a balance between enabling return and ensuring the basic needs of people already inside its borders. International support will greatly aid Rwanda's ability to meet its substantial obligations to both populations, which will ultimately promote security throughout the entire region. The adoption of the following suggestions could help Rwanda and its international supporters more equitably distribute land rights.

\section{A. Suggestions for Rwanda}

The government must create a mechanism for systematically resolving the land disputes that will continue to arise as returning people seek to reclaim their family plots. An adaptation of the Sri Lankan low-cost community mediation model could be a viable option for Rwanda. Rwanda would also benefit from international assistance in training mediators. Indeed, the most common criticism of the gacaca is the jurists' lack of training. The decisions of such mediation boards should carry full legal weight, but with the option of appeal to a court of law to check mediators' potential partiality. If the Rwandan government does pursue such a strategy, it should make efforts to protect women-headed and other vulnerable households from the risk of prejudicial board decisions by creating specific appellate routes to the courts.

Women's land security will remain tenuous so long as local officials retain broad discretionary power to allocate land rights. ${ }^{238}$ Gaps between existing local-customary law and formal laws, such as the Succession Law and the Land Use and Management Law, leave gray spaces and provide opportunities for the abusive exercise of discretion. ${ }^{239}$ Bridging these gaps with more comprehensive statutes would restrict the exercise of discretion in a way that would promote more equitable land access for all Rwandans, including women. Codification should not come at the expense of respect for local-customary traditions but instead should serve the purpose of bolstering the constitutionally required rights to equality so that all might participate fully in their cultural communities. The Rwandan government

237. Note, International Protection United Nations General Assembly Executive Committee of the High Commissioner's Programme Fifty-Fourth Session, 16 INT'L J. REFUGEE L. 124, 135 (2004); UNHCR GLOBAL REPORT 2004, supra note 9, at 158.

238. See supra notes 110-111 and accompanying text.

239. See generally Rose 2004, supra note 24 , at 218-21. 
should also establish checks on the discretion of local officials and Family Councils to tamper with the equitable allocation of land rights. Again, providing an appellate route to the courts would check local power abuses. People at risk of land insecurity should understand the legal options available to them, and free legal assistance should be available to those seeking appeal from local-level decisions.

Rights education is vital. Women and vulnerable returning people must know their land rights under domestic and international law and the processes by which they can realize them. Concomitantly, the government should train those local officials with allocatory power about the importance of women's land security to encourage land distribution that is in the best interests of the population as a whole. Rwandans have demonstrated a readiness to accept women's changing responsibilities since the genocide; the government should bolster this openness with educational outreach that affirms women's increasing independence and agency.

If the Rwandan government decides to pursue a policy of farm consolidation as described in the Land Use and Management Law, it must also immediately make available non-farm opportunities for those at risk of losing their land, particularly the majority of Rwandan women who earn their living from subsistence agriculture. This will require education and skills training so that people can undertake new roles. At the same time, the government should carefully consider the costs and benefits of moving to large-farm agriculture, particularly in terms of the loss of biodiversity and traditional social structures ordered around dispersed inhabitancy patterns.

\section{B. Suggestions for Rwanda's International Supporters}

Rwanda's international partners should pressure Rwanda to meet its legal obligations under guiding human rights treaties, particularly CEDAW and the refugee protocols. Rwanda has not submitted a report to the CEDAW Committee since 1993, indicating that it does not prioritize compliance with that document. In keeping with the Eviction Guidelines and the Internal Displacement Principles, Rwanda should extend special protection to IDPs as well as returning refugees.

However, at the same time that Rwanda should be encouraged to honor its commitments under international law, the international community should not exert pressure on Rwanda to conform with private-property regimes more common in western contexts, without respect for the small country's more communal forms of land regulation. Rwanda did not historically operate on the typically western private-property model assumed by these international treaties; instead Rwandans-before, during, and after colonization-have always vested centralized land ownership in a governing body, which has then allotted land-use rights. New obligations to honor the right of its citizens to own property, as established in treaties it has 
embraced, require Rwanda to bring its domestic land laws into compliance with international law and, particularly, to honor its duty to ensure that everyone within its jurisdiction has access to land for the purposes of shelter and subsistence. Yet just as foreign aid that demands a state adopt new models of land regulation hurts rather than helps that state's most vulnerable groups, as discussed above, tensions arise when a state enters into treaties that might conflict with its own customary law. This is not to say Rwanda should renounce its treaty obligations, but rather that a flexible approach that does not insist on individual private-property rights is better suited for Rwanda's parallel system of land regulation and historical land use patterns.

Rwanda's ability to respond to its land crisis would also benefit enormously from the provision of skills training, particularly in the areas of law and mediation. If international supporters do condition aid on compliance with these legal obligations, they must also provide Rwanda with the economic and personnel resources necessary to meet the requirements. No one can create more land in Rwanda, but international aid could help the country provide housing for the hundreds of thousands living in inadequate, temporary shelters on the imidugudu. On this view, the decision by the international community to express disapproval over the NHP by withholding aid was the wrong one, as it worsened conditions for the imidugudu residents rather than enabling Rwanda to pursue more constructive remedies to its land and refugee crisis. ${ }^{240}$

Because Rwanda must bolster its legal system before it can provide consistent and widely available appellate adjudication, international aid could also help train more lawyers, judges, and mediators. The success of the CDPR and the Sri Lankan models both hinged on their cultural specificity and international support. With similar assistance in ways that are appropriate to Rwanda's unique blend of circumstances, the international community could significantly help Rwanda resolve disputed land claims in procedurally fair ways by offering training and legal expertise. In providing this support, however, international groups should also be sensitive to the implications of traditional adversarial adjudication in this postgenocide setting, making sure that any assistance promotes the well-being of all Rwandans without any connotations of "victor" and "loser."

Rwanda also requires assistance incorporating into the global economy. Much of its poverty could be alleviated by reducing its dependency on foreign aid as it transitions to a self-sufficient economy. Rwanda's international trade activity is currently dictated by the WTO, which limits options available to local communities and obliterates indigenous sectors of the domestic economy. ${ }^{241}$ In response to globalization's demands to

240. See Ensuring Durable Solutions, supra note 63, at 9

241. HuGGins ET AL. 2005, supra note 35, at 5. 
modernize and marketize, developing states desperate for a position in the global market are sometimes forced to abandon traditional land-use patterns and indigenous crops in favor of individually-owned, large tracts capable of producing cash crops like maize, tobacco, or rice, rather than local-customary models that incorporate communal use rights and the allocation of small plots for subsistence farming of indigenous crops. Rwanda should not be forced to adopt culturally inappropriate models in order to receive much needed aid. As a report by the African Centre for Technology Studies notes, "[1]and rights, like all property rights, are socially-mediated entitlements .... This explains the tenacity of customary forms of tenure, despite the fact that statutory law has largely ignored them."242 Sound land reform should promote rather than diminish the "stability and local relevance of social groups."243 Establishing this connection to traditional schemes indicates the very foreign nature of private title in the Rwandan context. As in the Sri Lankan and Balkan examples, where culturally responsive dispute-resolution structures promoted their efficacy, any viable scheme for land reform in Rwanda must acknowledge Rwandans' unique and vital connection to communally held land.

In many ways, Rwanda in 2006 demonstrates astounding success. The country has emerged out of desperate poverty, violence, and inter-ethnic hatred to become a functioning state that has accepted new roles for women. However, it continues to face many challenges, particularly the crisis of land shortage. With the help of the international community and a continued dedication to protecting the land rights of its most vulnerable members, Rwanda will surely continue to progress down the path to lasting peace.

APPENDIX A:

Abrreviations and Kinyarwanda Terms

abatware b'umukenke - chiefs vested with authority to allocate use rights to the mwami's land.

Annex VII - annex to the Dayton Peace Accords ending hostilities between the former Yugoslav republics.

CERD - International Convention on the Elimination of All Forms of Racial Discrimination.

colline - French for hill; also the smallest political subdivision in Rwanda. Rwanda is commonly referred to as the "land of mille collines," or land of a thousand hills.

commune - the third largest political subdivision in Rwanda. Each commune is headed by a bourgmestre, who presides over the commune's communal counsel.

242. Id.

243. Id. 
CDPR - Commission for Displaced Persons and Refugees, created under Annex VII to resolve property disputes in some former Yugoslav republics. DRC - Democratic Republic of Congo.

imidugudu - settlements, part of the National Habitat Policy of villagization.

isambu - centralized system of land regulation used by the ruling Tutsi royalty until colonization.

ICCPR - International Covenant on Civil and Political Rights.

ICESCR - International Covenant on Economic, Social, and Cultural Rights.

ICTR - International Criminal Tribunal for Rwanda.

IMF - International Monetary Fund.

Kigali ville - the city of Kigali, as opposed to Kigali préfecture.

Kinyarwanda - Rwanda's national language. Kinyarwanda, French, and English are all official languages.

mwami - Kinyarwanda term for "king."

NHP - National Habitat Policy.

prefecture - the largest political subdivision in Rwanda. Rwanda has twelve préfectures, each headed by a préfet. The préfectures are themselves divided into subpréfectures.

RPF - Rwandan Patriotic Front. Formerly an exile army, the RPF is now a political party detached from the military.

secteur - the second smallest political subdivision in Rwanda.

Succession Law - Matrimonial Regimes, Liberties and Succession Law of 2000, CC No. 22/99 of Dec. 11, I999.

ubukonde - land tenure system used for regulating land use in the northwest provinces until colonization, and still the guiding system in Ruhengeri and Gisenyi préfectures.

ubureetwa - forced labor extractions in exchange for land rights.

umudugudu - singular of imidugudu.

umuheto - gifts given periodically to patrons by client lineages, often the gift of a cow.

umukonde - lineage head in charge of allocating land use among the lineage.

UNAMIR - United Nations Assistance Mission to Rwanda.

UNCHS - United Nations Centre for Human Settlements (Habitat).

UNHCR - United Nations High Commissioner for Refugees.

USAID - U.S. Agency for International Development.

USCR - U.S. Committee for Refugees. 
APPENDIX B:

MAP OF RWANDa

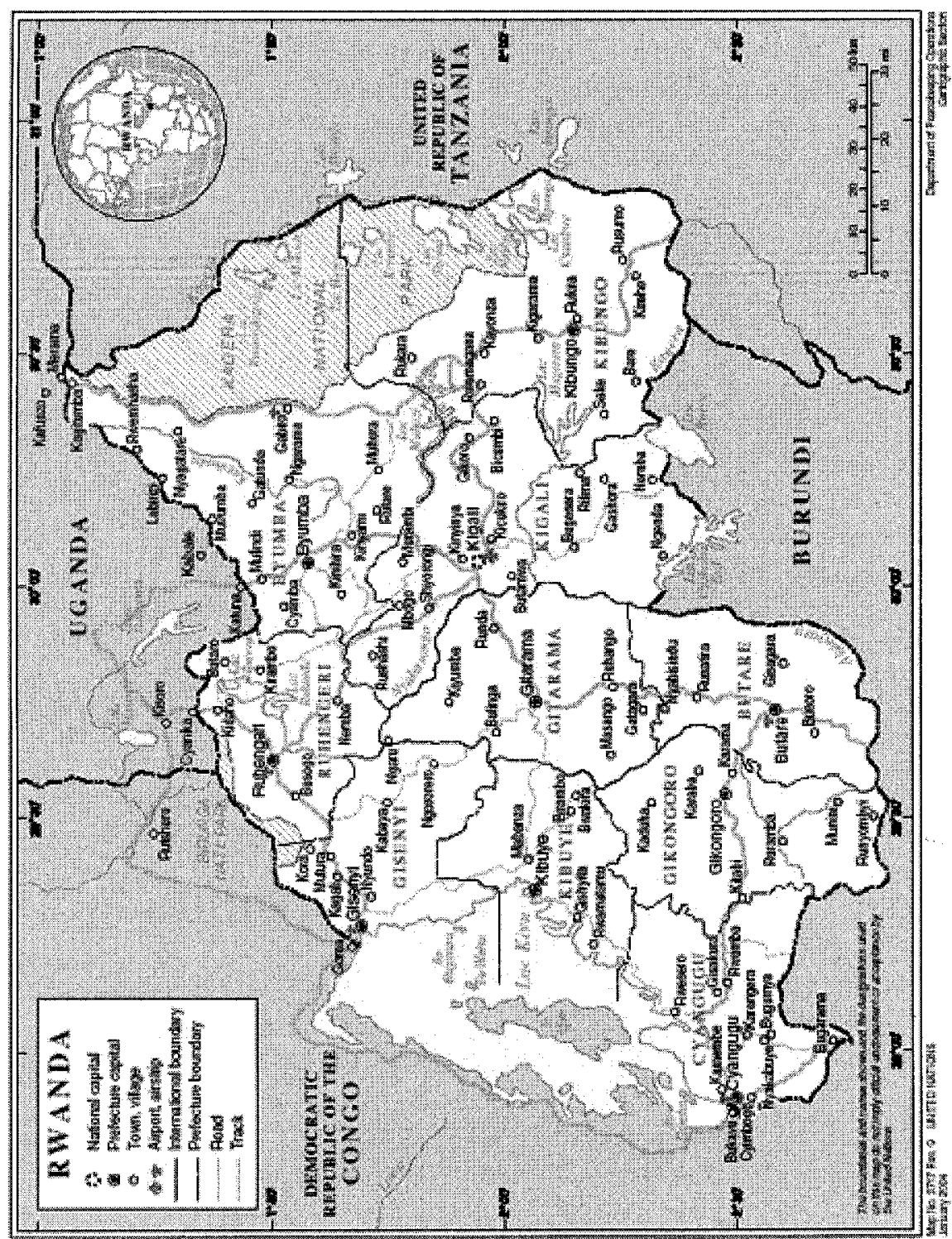

